\title{
Promjene u sastavu stanovništva prema narodnosti u Karlovačkoj i Ličko-senjskoj županiji od 1991. do 2011.
}

DOI: $10.11567 /$ met.31.2.4 UDK: 314:323.11](497.5-35Karlovac)"1911/2011" 314:323.11](497.5-35Gospić)"1911/2011"

Prethodno priopćenje

Primljeno: 30. 04. 2015. Prihvaćeno: 06. 12. 2015.

\section{Ivo Turk}

Institut društvenih znanosti »/vo Pilar«, Zagreb

ivo.turk@pilar.hr

\section{Nikola Šimunić}

Institut društvenih znanosti »/vo Pilar«, Područni centar Gospić, Gospić

nikola.simunic@pilar.hr

\section{Marta Jovanić}

Vinkovci

marta.jovanic@gmail.com

\section{SAŽETAK}

$\mathrm{U}$ radu se proučavaju promjene u sastavu stanovništva prema narodnosti u Karlovačkoj i Ličko-senjskoj županiji od 1991. do 2011. te se analiziraju čimbenici koji su utjecali na te promjene. Posebna se važnost pridaje proučavanju dviju najzastupljenijih etničkih skupina - Hrvata i Srba. Analizom popisnih podataka pokazuje se da su najveće promjene zabilježene u prvome međupopisnom razdoblju od 1991. do 2001. što autori vežu uz zbivanja povezana s emigracijom, Domovinskim ratom, starenjem stanovništva i promjenama u popisnim metodologijama. Prema popisu stanovništva iz 1991., u obje je županije većinski bilo prisutno stanovništvo hrvatske narodnosti, dok su Srbi predstavljali najbrojniju nacionalnu manjinu sa značajnim udjelom od 25,4\% u Karlovačkoj te 36,4\% u Ličko-senjskoj županiji. Popis iz 2001. bilježi nacionalnu homogenizaciju u narodnosnom sastavu stanovništva obiju županija s izraženijom dominacijom Hrvata (oko $85 \%$ u obje županije). Najnoviji popis stanovništva iz 2011. nije donio znatnije promjene $u$ narodnosnom sastavu u odnosu na prethodni u Karlovačkoj županiji, dok je u nekim dijelovima Ličko-senjske županije zabilježena značajnija promjena zbog povratka hrvatskih građana srpske nacionalne pripadnosti. Proučavana se problematika sagledava i u kontekstu krajnje nepovoljnoga općeg demografskog stanja okarakteriziranog izrazitim starenjem stanovništva i depopulacijom u dvije promatrane županije te nepovoljnim ekonomskim prilikama u njima.

KLJUČNE RIJEČI: narodnosni sastav, migracije, depopulacija, Domovinski rat, Karlovačka županija, Ličko-senjska županija 


\section{UVOD}

U Hrvatskoj je u posljednjih 25 godina došlo do značajnih promjena u narodnosnom sastavu stanovništva, a one su upravo najizraženije u dijelovima Hrvatske koji su bili zahvaćeni Domovinskim ratom (Živić, 2001, 2005). Početkom rata sa okupiranih je prostora protjerivano nesrpsko stanovništvo, da bi najveći dio Srba izbjegao u Srbiju i Bosnu i Hercegovinu u kolovozu 1995., tijekom vojno-redarstvene operacije »Oluja«. Iako egzaktnih podataka o ukupnom broju izbjeglica nema, procjenjuje se da je 1991./1992. ukupno bilo raseljeno 550.000 ljudi, a računa se da je 1995. Hrvatsku napustilo 250.000 pripadnika srpske nacionalnosti (Mesić i Bagić, 2011: 29).

U radu se proučava promjena u sastavu stanovništva prema narodnosti u Karlovačkoj i Ličko-senjskoj županiji ${ }^{1}$ od 1991., kada se Hrvatska osamostalila, do posljednjeg popisa stanovništva 2011. Razlog odabira tih županija jest činjenica da su one bile direktno zahvaćene ratnim zbivanjima tijekom Domovinskog rata, što je značajno utjecalo na promjenu narodnosnog sastava njihovog stanovništva. Obje su županije etnički miješane, iako većinu stanovništva čine Hrvati, dok su Srbi najbrojnija nacionalna manjina.

Od ukupno 314.689 izbjeglica u Srbiji za koje je bilo poznato prijeratno prebivalište, sredinom 1996. najviše ih je bilo podrijetlom iz Sisačko-moslavačke županije (70.648 ili 22,5\%), Šibensko-kninske (49.410 ili 15,7\%), Zadarske (41.676 ili 13,2\%), Karlovačke (32.205 ili 10,2\%), Ličko-senjske (27.317 ili 8,7\%), Osječko-baranjske (15.905 ili 5,1\%) i Požeško-slavonske (12.108 ili 3,8\%) (Živić, 2014: 309).

Prema »Izvješću o povratku prognanika i izbjeglica u Republici Hrvatskoj 2000. - 2003.« koje je objavilo Ministarstvo za javne radove, obnovu i graditeljstvo 2003., u Hrvatskoj su ukupno od početka procesa povratka 1995. do kraja rujna 2003. registrirana 315.102 povratnika. Od toga je 209.297 povratnika bivših prognanika, uglavnom Hrvata, koji su tijekom progonstva boravili u drugim područjima Hrvatske koja nisu bila zahvaćena ratom (oko 66\% od ukupnog broja povratnika). Zabilježeno je i 105.805 povrataka hrvatskih građana srpske nacionalnosti (oko 34\% ukupnog broja povratnika). Relevantni podaci po županijama, gradovima i općinama nisu dostupni. Mesić i Bagić (2011) navode da se u bazi registriranih manjinskih povratnika nalazi nešto više od 130.000 osoba (Mesić i Bagić, 2011). U kontekstu Hrvatske, povratak i reintegracija odvijaju se u uvjetima dubokih

\footnotetext{
Karlovačka županija obuhvaća pet administrativnih gradova i sedamnaest općina s ukupno 649 naselja, a Ličko-senjska četiri administrativna grada i osam općina s 258 naselja. Obje županije imaju manju gustoću naseljenosti od hrvatskog prosjeka (75,7 stanovnika po km²); Karlovačka 35,5 st. $/ \mathrm{km}^{2}$, a Ličko-senjska samo 9,5 st. $/ \mathrm{km}^{2}$.
} 
promjena (ekonomskih i političkih), pa su samim time i navedeni procesi otežani, te je potrebno uložiti dodatne napore da bi se izbjeglom stanovništvu omogućila reintegracija u hrvatsko društvo.

Domovinski je rat, kojim su ove županije izravno bile zahvaćene, dodatno pogoršao već ionako loše demografsko stanje, što se negativno odrazilo na ukupne demografske pokazatelje istraživanih županija (Pejnović, 2004; Nejašmić, 2008; Turk, 2009). Uz vanjske čimbenike demografskog razvoja, kakav je nedvojbeno rat sa svojim stradanjima, na razvoj narodnosnog sastava ovih dviju županija ponajviše su utjecala prisilna migracijska kretanja stanovništva. Iako je težište rada na promjenama u sastavu stanovništva prema narodnosti, radi boljeg razumijevanja trenutačne demografske situacije potrebno je analizirati i osnovne pokazatelje dinamike stanovništva te razinu starenja. Obje županije karakteriziraju nepovoljni demografski procesi: depopulacija, prirodni pad broja stanovnika, emigracija i starenje stanovništva.

\section{DEMOGRAFSKA DINAMIKA I STARENJE STANOVNIŠTVA}

Na početku 20. stoljeća, promatrane županije imale su gotovo podjednak broj stanovnika. Ukupni broj stanovnika Karlovačke županije bio je 194.294, dok je u Ličko-senjskoj tada živio 186.871 stanovnik. Sve veći raskorak u broju stanovnika između ove dvije županije javlja se nakon Drugoga svjetskog rata kada Ličko-senjska županija značajno zaostaje u gospodarskom razvoju te 1960-ih ima najnižu prosječnu stopu rasta nacionalnog dohotka, što je i razlog intenzivne emigracije iz tog područja (Pejnović, 2004). Gospodarsko i demografsko zaostajanje ove županije nastavilo se i u narednim desetljećima što je vodilo nastavku iseljavanja i značajnom pogoršanju demografskih i ekonomskih struktura. Nastavljaju se nepovoljne tendencije $u$ prirodnom kretanju, pa 1980-ih sve tadašnje ličke općine bilježe prirodno smanjenje stanovništva (Pejnović, 1991). Tijekom 1950-ih Karlovačka županija bilježi osrednju progresiju stanovništva uglavnom zbog prirodnog kretanja, uz istovremeno napuštanje ruralnih područja i koncentraciju stanovništva u gradska industrijska središta. S otvarenjem granica 1960-ih, započinje iseljavanje posebice iz ruralnih dijelova županije $u$ inozemstvo, što rezultira općom, a od 1980-ih i prirodnom depopulacijom (Turk, 2007). 
Slika 1. Kretanje broja stanovnika u Karlovačkoj i Ličko-senjskoj županiji 1948. - 2011.

Figure 1. Population trends in Karlovac and Lika-Senj Counties, 19482011

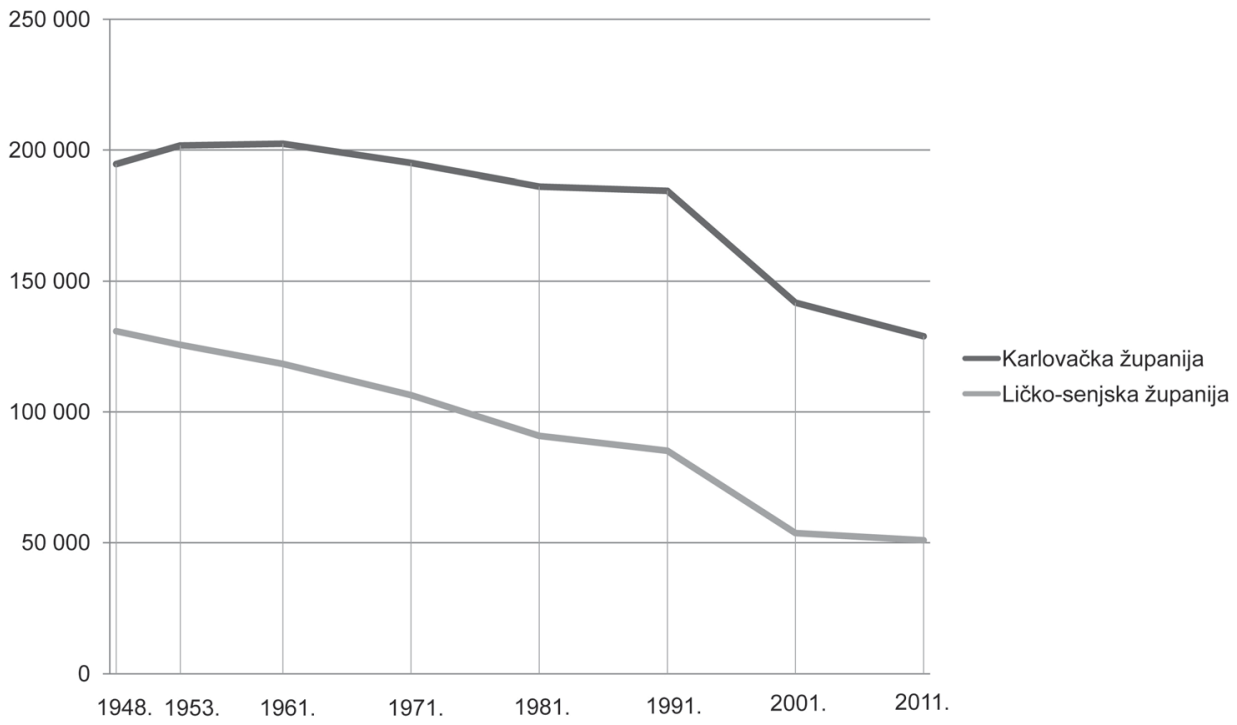

Izvor: www.dzs.hr.

U zadnjem desetljeću 20. stoljeća nastavljaju se negativni gospodarski i demografski procesi, koji će se uslijed ratnih događanja još dodatno intenzivirati. Tako je u ovom razdoblju u Karlovačkoj županiji broj stanovnika smanjen sa 184.577 na 141.787 (indeks promjene 76,8), a u Ličko-senjskoj s 85.135 na 53.677 (indeks promjene 63,1). Iako su brojni razlozi takva smanjenja broja stanovnika, jedan od najvažnijih bio je Domovinski rat, koji je prouzročio izravne i neizravne demografske gubitke (Radelić i sur., 2006; Živić, 2009). Tijekom Domovinskog rata u Karlovačkoj županiji je poginulo 555 hrvatskih branitelja, a 9 je nestalih. Broj poginulih i nestalih Srba rođenih u Karlovačkoj županiji iznosi 438 (Živić, 2005; Radelić i sur., 2006). U Domovinskom ratu u Ličko-senjskoj županiji poginulo je 245 hrvatskih branitelja, a nestala su četvorica. Broj poginulih Srba rođenih u Ličko-senjskoj županiji jest 692 (Živić, 2005; Radelić i sur., 2006), poginulih civila od 17. kolovoza 1990. do 25. ožujka 1999. na Kordunu 157, a u Lici 106² (Živić, 2005;

2 Nisu dostupni podaci za županije, nego samo za navedene regije. 
Radelić i sur., 2006). U neizravne demografske gubitke mogu se ubrojiti i svi stanovnici koji su se zbog okolnosti prouzročenih Domovinskim ratom u to vrijeme iselili ili izbjegli iz Hrvatske (Nejašmić, 2014). Njihov točni broj nije poznat. Loše ekonomske prilike također su uzrokovale iseljavanje. Metodološke razlike između dva navedena popisa svakako su pridonijele takvu smanjenju broja stanovnika jer je popis stanovništva iz 1991. proveden po takozvanom de iure principu, dok je popis iz 2001. proveden po modificiranom de facto principu (Pokos, 2003; Radelić i sur., 2006). Ipak, unatoč promjeni metodologije popisa stanovništva ratne okolnosti i ekonomska kriza ključni su čimbenici depopulacije.

$S$ druge strane, prirodno-geografski čimbenici također su značajno utjecali na povijesni razvoj naseljenosti obiju županija. To se ponajprije odnosi na krški reljef koji je bio zapreka ujednačenom demografskom razvoju i utjecao je na nastanak disprezne naseljenosti (Turk, 2007). Na cijelome promatranom prostoru jedino je urbano naselje s više od 10.000 stanovnika i značajnijim funkcijama Karlovac, što je vrlo nepovoljno za ravnomjerniji demografski razvoj. Zbog spleta povijesnih okolnosti u Ličko-senjskoj županiji nikada se nije razvio nijedan grad srednje veličine koji bi mogao imati značajniju centralnu ulogu u prostoru i na taj način okupiti stanovništvo (Pejnović, 2004). Od sredine sedamdesetih do početka devedesetih godina 20. stoljeća Lika je bila jedina regija u Hrvatskoj u kojoj su se sve općine nalazile u kategoriji gospodarski nedovoljno razvijenih krajeva (Pejnović, 1996). Lika je jedan od klasičnih emigracijskih krajeva Hrvatske, iz koje je prvo veće iseljavanje već počelo nakon razvojačenja Vojne krajine krajem 19. stoljeća i od tada se zapravo emigracija kontinuirano odvija različitim intenzitetom (Pejnović, 1991, 1996).

U prvome promatranome međupopisju (1991. - 2001.) svi gradovi i općine Karlovačke županije bilježe značajno smanjenje broja stanovnika na što je utjecalo više čimbenika. Najvažniji su od njih Domovinski rat, loša ekonomska situacija i promjene popisnih metodologija (Pokos, 1999). Zbog nepotpune vitalne statistike za razdoblje od 1991. - 1995., vrijednost migracijske bilance za prostore koji su bili okupirani treba uzeti s rezervom. Ipak, najnepovoljnije stope migracijske bilance općenito bilježe gradovi/općine koji su tijekom Domovinskog rata bili okupirani (Plaški, Cetingrad, Slunj i Saborsko). Procjenjuje se da je 23.374 stanovnika Karlovačke županije 1998. živjelo u inozemstvu (Pokos, 1999). 


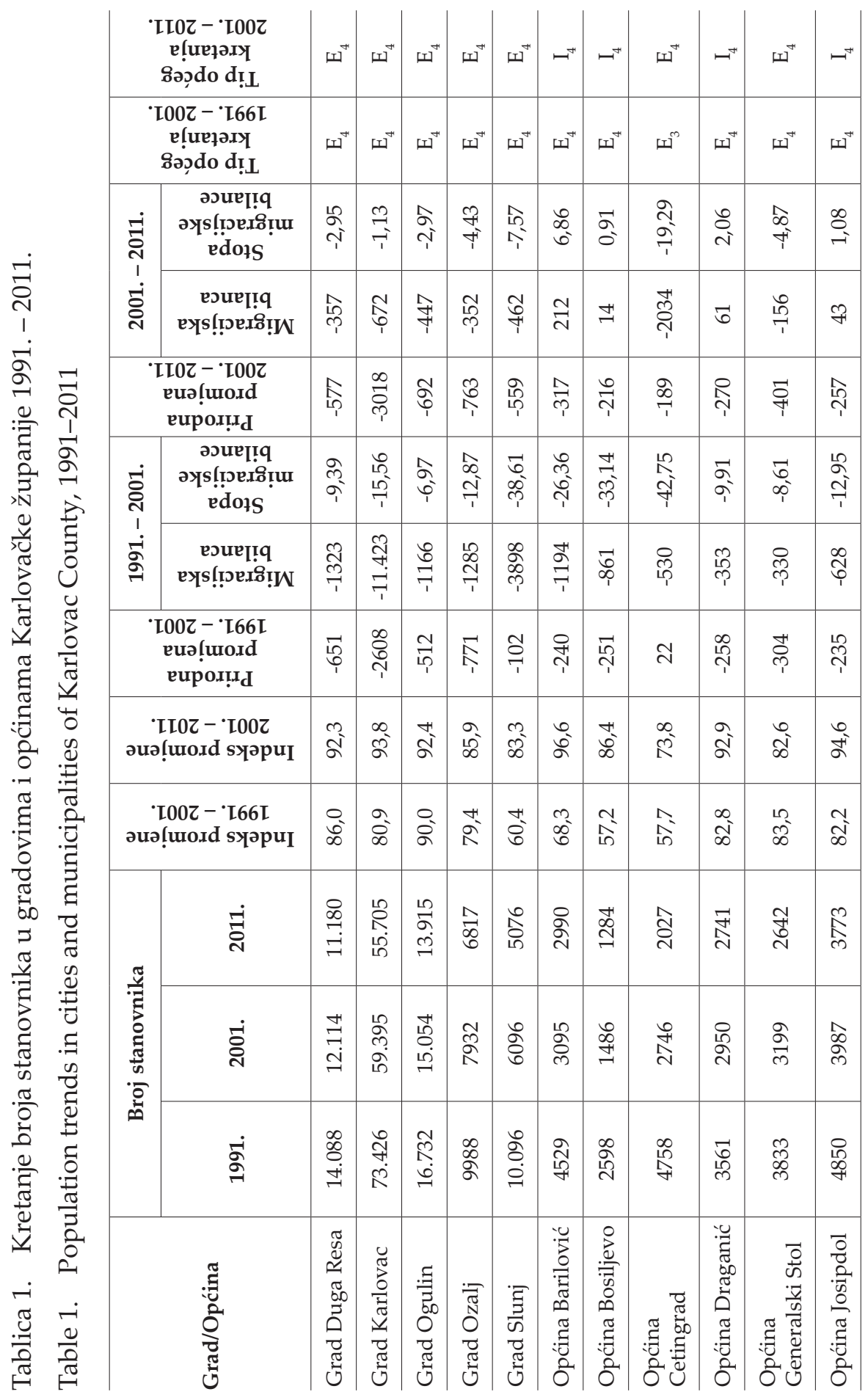




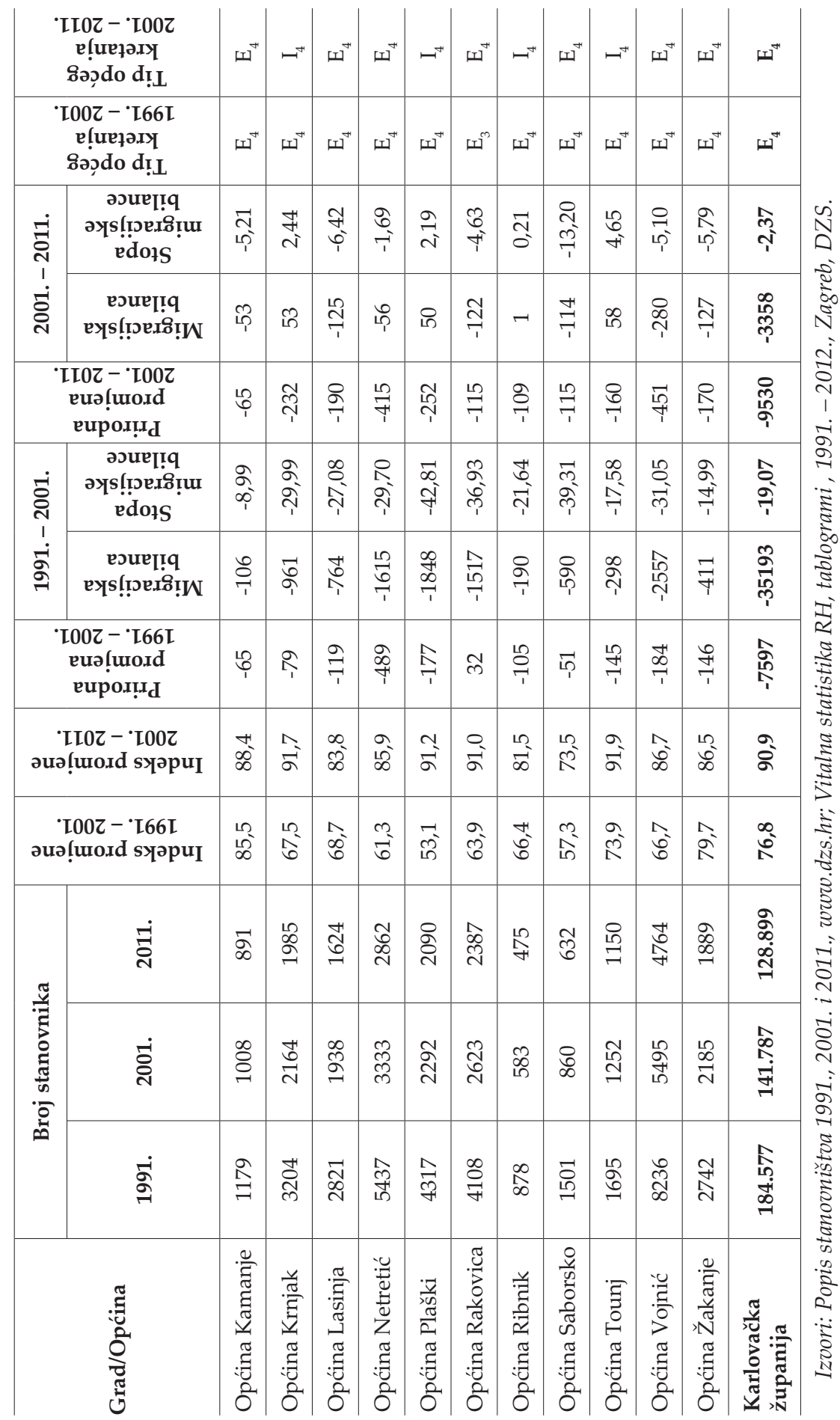




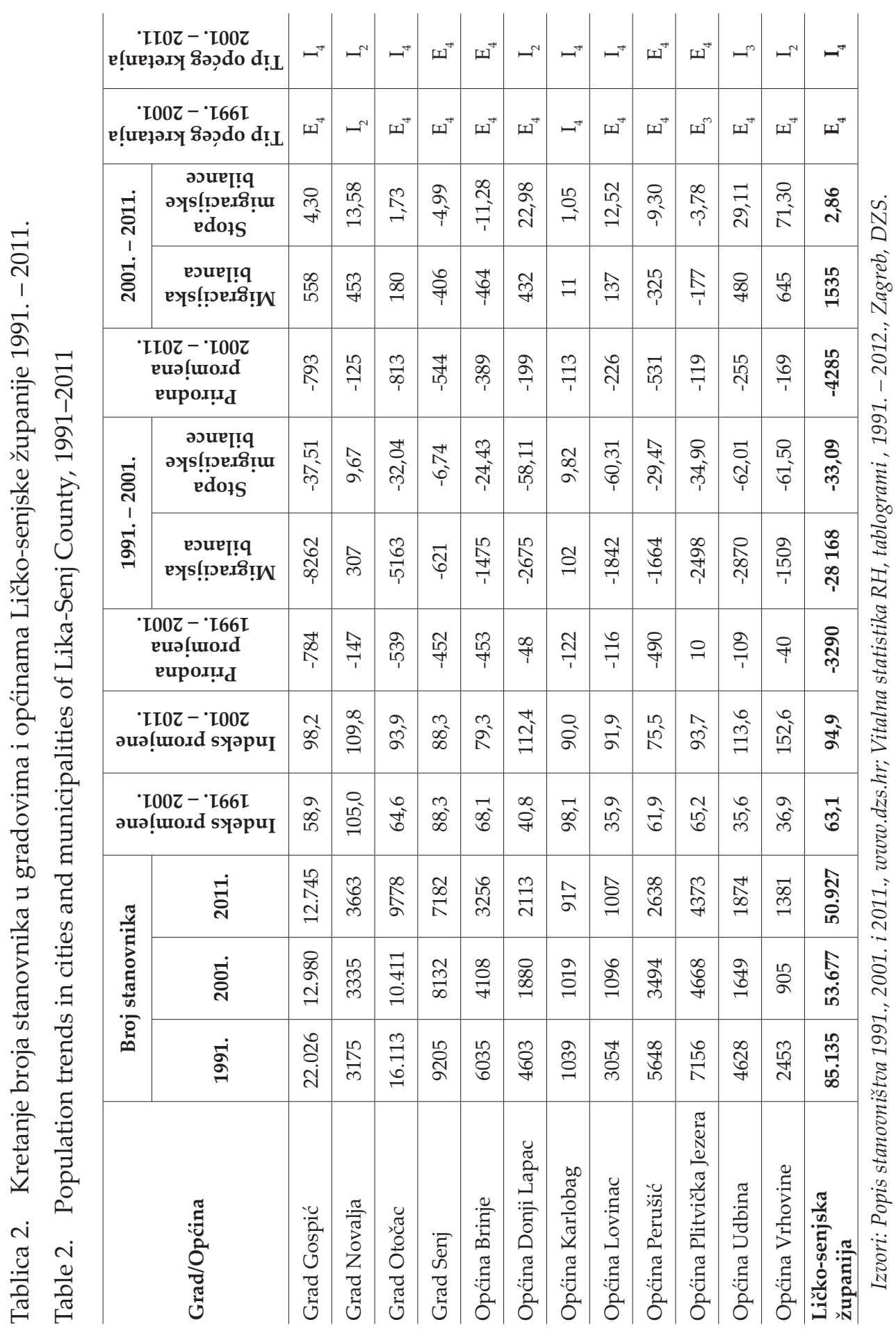


U sljedećem je međupopisju (2001. - 2011.) došlo do smanjenja intenziteta ukupne depopulacije, no ona je svejedno zabilježena u svim gradovima i općinama (tablica 1). Razlozi su za takvo stanje prestanak ratnih zbivanja, što je popraćeno povratkom dijela stanovništva izbjeglog $u$ prethodnome međupopisju, te manje razlike popisnih metodologija. Stoga ne iznenađuje da osam općina bilježi pozitivnu migracijsku bilancu, odnosno imigraciju. Za općine Barilovići, Krnjak, Josipdol, Plaški i Tounj može se pretpostaviti da je riječ o povratku izbjeglih osoba uglavnom srpske nacionalnosti. Imigracija u općinu Draganić vjerojatno je posljedica suburbanizacije Karlovca, dok je imigracija u općinu Bosiljevo, a poglavito u općinu Ribnik, toliko mala (zanemariva) da je teško ustvrditi njezin pravi uzrok. U svakom slučaju, ukupni iznos imigracije u općinama koje su je zabilježile malen je i ne upućuje na poboljšanje ukupnih demografskih trendova.

U Ličko-senjskoj županiji, općenito gledajući, u prvom je promatranome međupopisju intenzitet depopulacije bio veći od onoga u Karlovačkoj županiji (tablica 2). Migracijska je bilanca negativna i emigracija je prisutna u svim gradovima/općinama, a najnepovoljnije stope migracijske bilance bilježe općine koje su u Domovinskom ratu bile okupirane i koje su prema popisu stanovništva iz 1991. imale veliki udio Srba u ukupnoj populaciji. Procjenjuje se da su 12.952 stanovnika Ličko-senjske županije 1998. živjela u inozemstvu (Pokos, 1999). Gotovo svi su gradovi i općine imali značajnu depopulaciju. Grad Novalja, koji se nalazi na otoku Pagu, jedini bilježi porast broja stanovnika i to kao rezultat doseljavanja, što je prije svega vezano uz tamošnji vrlo razvijeni turizam. ${ }^{3}$ I Općina Karlobag u ovom međupopisnom razdoblju bilježi pozitivnu migracijsku bilancu. Riječ je o primorskoj općini gdje nije bilo izravnih ratnih sukoba i gdje je razvoj turizma generirao imigraciju.

U sljedećemu međupopisju (2001. - 2011.) intenzitet depopulacije osjetno se smanjio. Iako se nastavlja prirodna depopulacija, županija bilježi pozitivan migracijski saldo. Vrijednost imigracije nije velika i sigurno je da ne može pozitivno utjecati na poboljšanje cjelokupne demografske situacije. Uz Grad Novalju porast broja stanovnika bilježe i općine Donji Lapac, Udbina i Vrhovine. Riječ je o općinama koje su prema popisu iz 1991. imale većinsko stanovništvo srpske narodnosti, koje je 1990-ih u velikom broju iselilo ili izbjeglo u Srbiju i Bosnu i Hercegovinu. Valja pretpostaviti da je pozitivna vrijednost migracijske bilance u Gradu Novalji i Općini Karlobagu posljedica pozitivnog utjecaja turizma na demografske tijekove. U svim

${ }^{3}$ Moguće je da je to povećanje broja stanovnika vezano i uz pojavu fiktivnog popisivanja stanovništva na otocima radi stjecanja određenih beneficija. 
ostalim gradovima/općinama imigracija je najvećim dijelom uzrokovana povratkom stanovništva koje je izbjeglo tijekom Domovinskog rata. Općine Brinje i Perušić 1991. nisu imale značajniji udio Srba pa stoga i nema povratničkih tokova u tom razdoblju. Očito je da su povratnički tokovi u Općinu Plitvička Jezera slabi jer i ona bilježi emigraciju. Zanimljiv je primjer Grada Senja, koji nije bio izravno zahvaćen ratnim razaranjima i koji ima primorski položaj, a bilježi emigraciju. Razlog je tome činjenica što Senj nikada nije razvio turizam do mjere u kojoj je on bio ili jest zastupljen u okolnim gradovima/općinama, pa manjka ekonomska »gravitacijska sila« koja bi privukla stanovništvo.

Prirodno je kretanje stanovništva u obje županije vrlo nepovoljno te ga karakterizira veći broj umrlih nego rođenih. Vrijednosti stope prirodne promjene kretale su se u Karlovačkoj županiji od -3,3\%o u 1994. do -7,8\% u 2011., a u Ličko-senjskoj od -3,1\% u 1997. do -9,8\% u 2012. ${ }^{4}$ Povećanje intenziteta prirodne depopulacije povezano je s dugotrajnim emigracijskim procesima i starenjem stanovništva (Nejašmić, 1991, 2005, 2008; Pejnović, 2004; Akrap i Gelo, 2009).

${ }^{4}$ Za razdoblje od 1991. do 1995. podaci vitalne statistike nisu potpuni. Na tada okupiranim područjima ovih županija tamošnje vlasti nisu vodile vitalnu statistiku, pa su dostupni podaci samo za živorođene i umrle iz okupiranih prostora koji su se nalazili na teritoriju pod kontrolom hrvatskih vlasti (prognanici) (Akrap, 1999; Akrap i Gelo, 1999). 
Slika 2. Prirodno kretanje stanovništva u Karlovačkoj županiji 1991. 2012.

Figure 2. Natural change in Karlovac County, 1991-2012

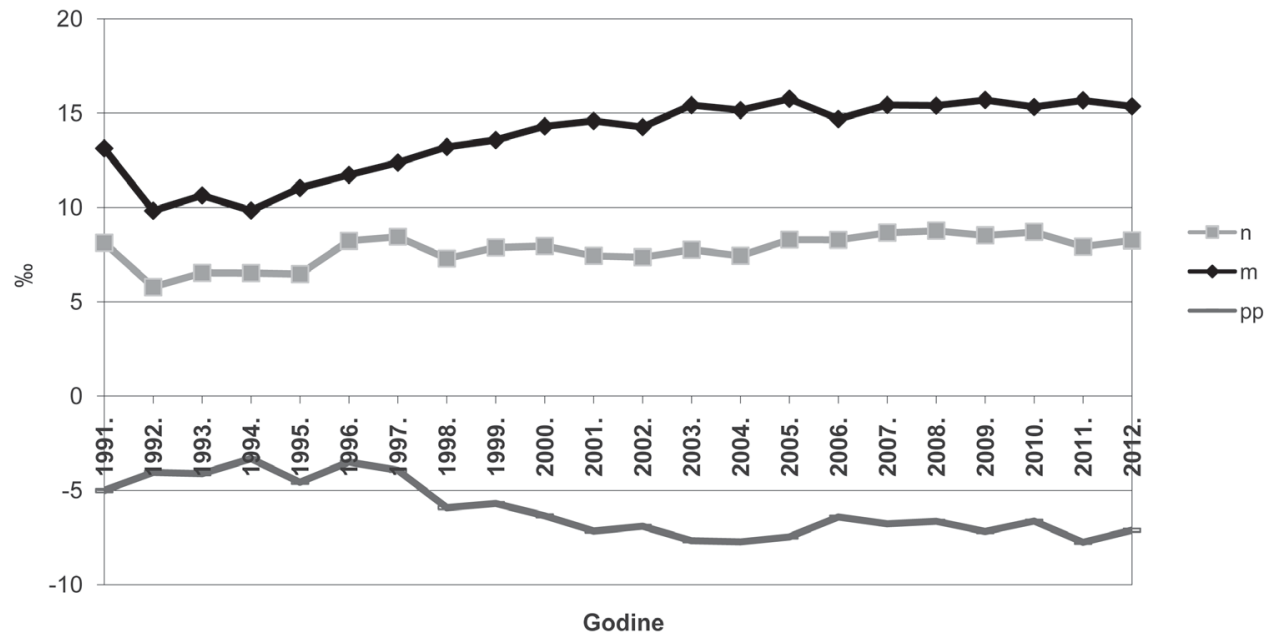

Izvor: Vitalna statistika RH, tablogrami, 1991. -2012., Državni zavod za statistiku, Zagreb.

Slika 3. Prirodno kretanje stanovništva u Ličko-senjskoj županiji 1991. 2012.

Figure 3. Natural change in Lika-Senj County, 1991-2012

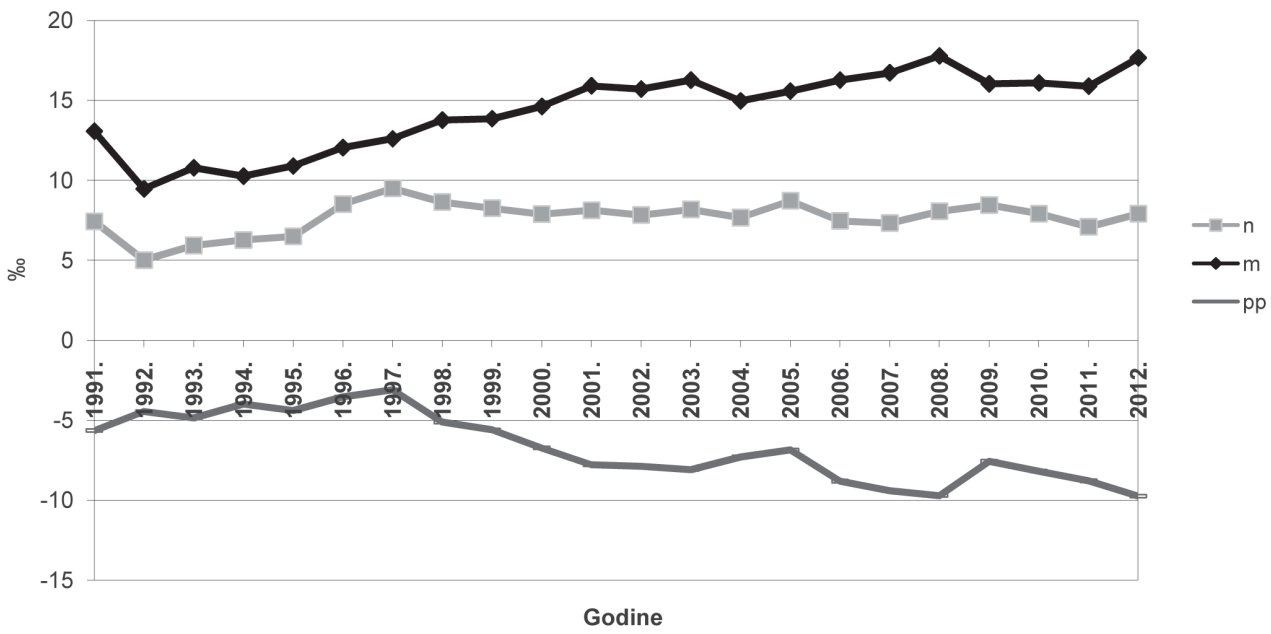

Izvor: Vitalna statistika RH, tablogrami, 1991. -2012., Državni zavod za statistiku, Zagreb. 
Slika 4. Tipovi općega kretanja stanovništva u gradovima/općinama Karlovačke i Ličko-senjske županije 1991. - 2001.

Figure 4. Types of overall population trends in cities/municipalities of Karlovac and Lika-Senj Counties, 1991-2001

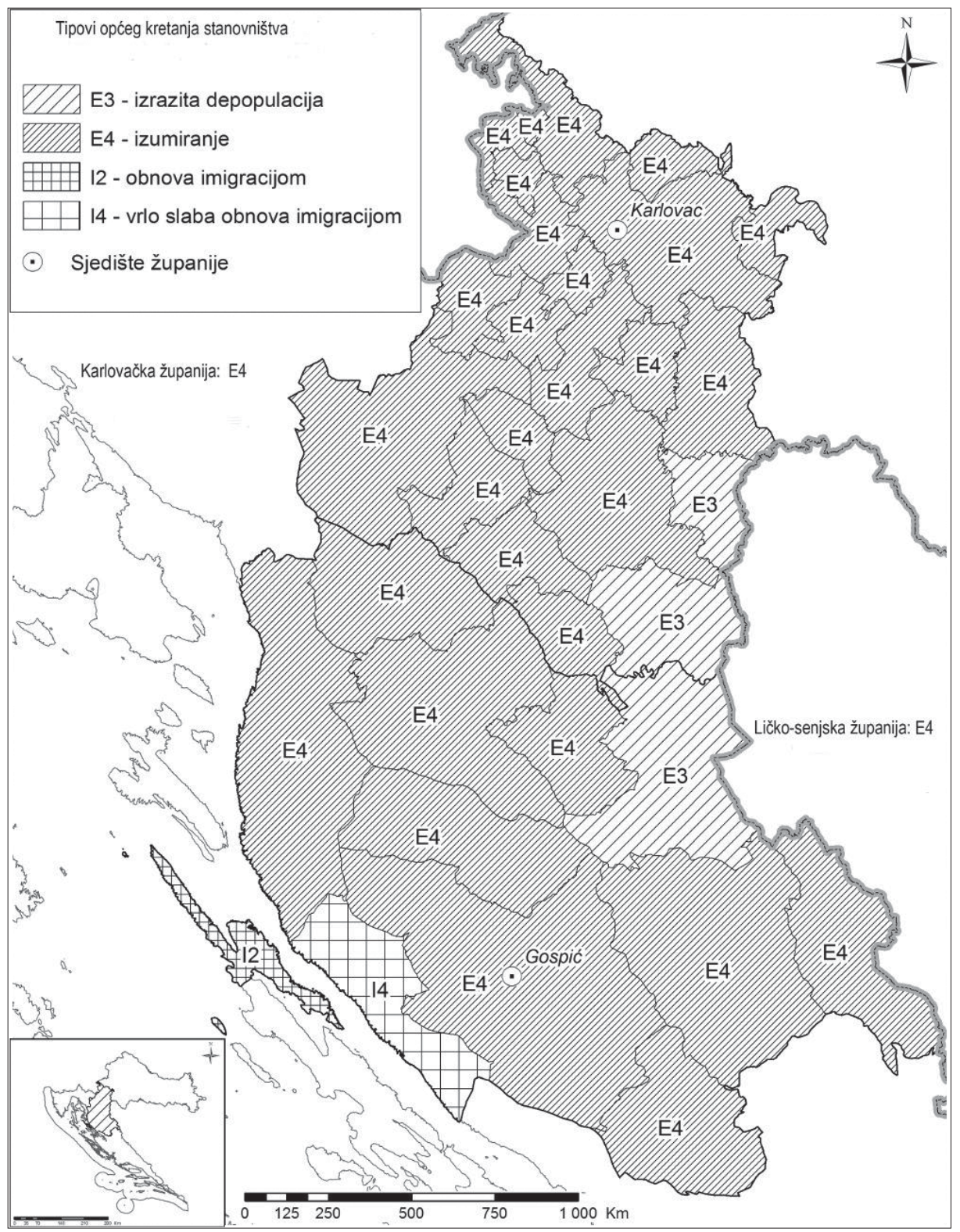


Slika 5. Tipovi općega kretanja stanovništva u gradovima/općinama Karlovačke i Ličko-senjske županije 2001. - 2011.

Figure 5. Types of overall population trends in cities/municipalities of Karlovac and Lika-Senj Counties, 2001-2011

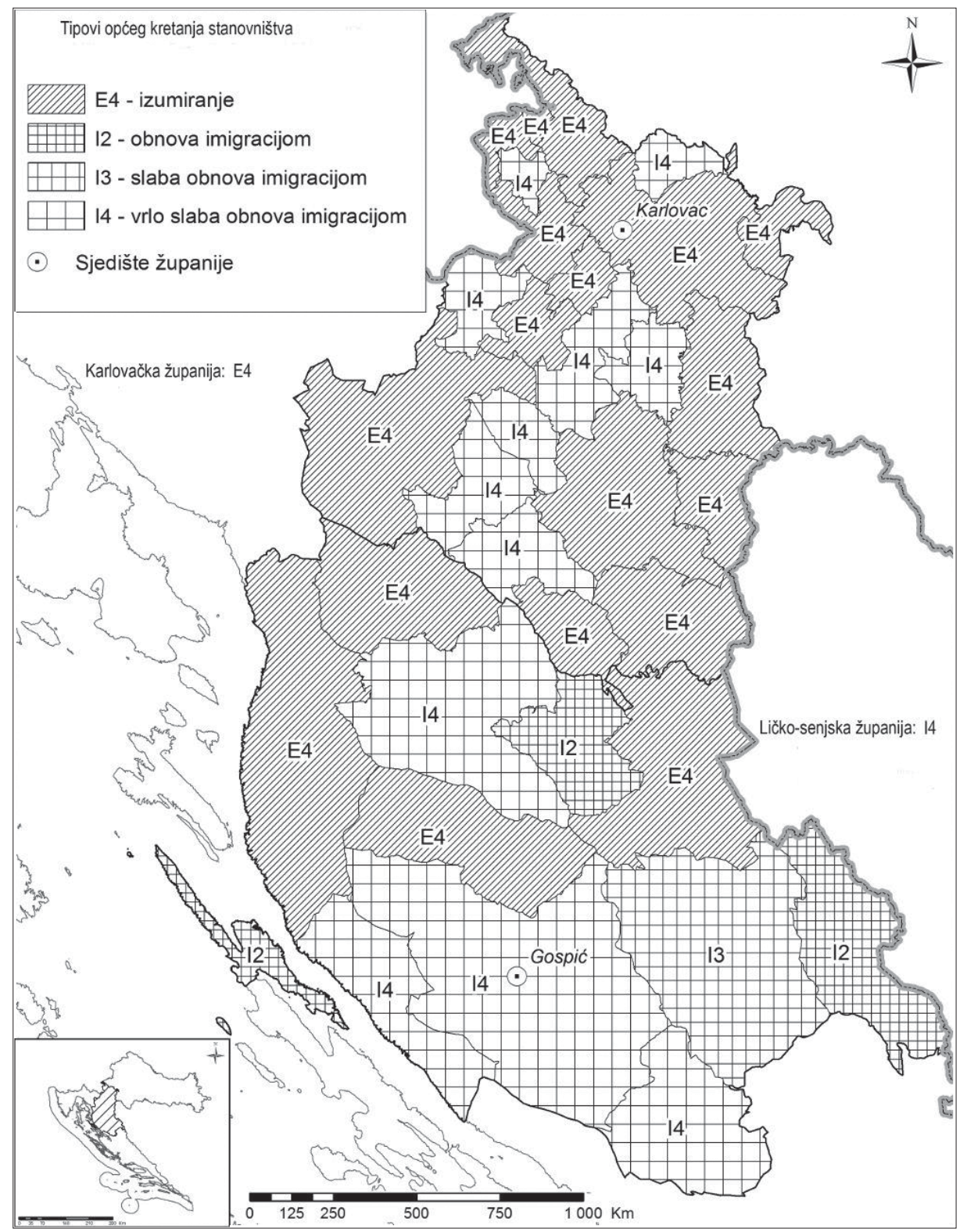


Slika 6. Tipovi ostarjelosti stanovništva u Karlovačkoj i Ličko-senjskoj županiji 1991.

Figure 6. Types of population ageing in Karlovac and Lika-Senj Counties in 1991

Tip ostarjelosti 1991.

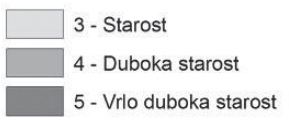

Karlovačka županija: 3 - Starost

Ličko-senjska županija: 5 - Vrlo duboka starost

- Sjedište županije

- Granica županije

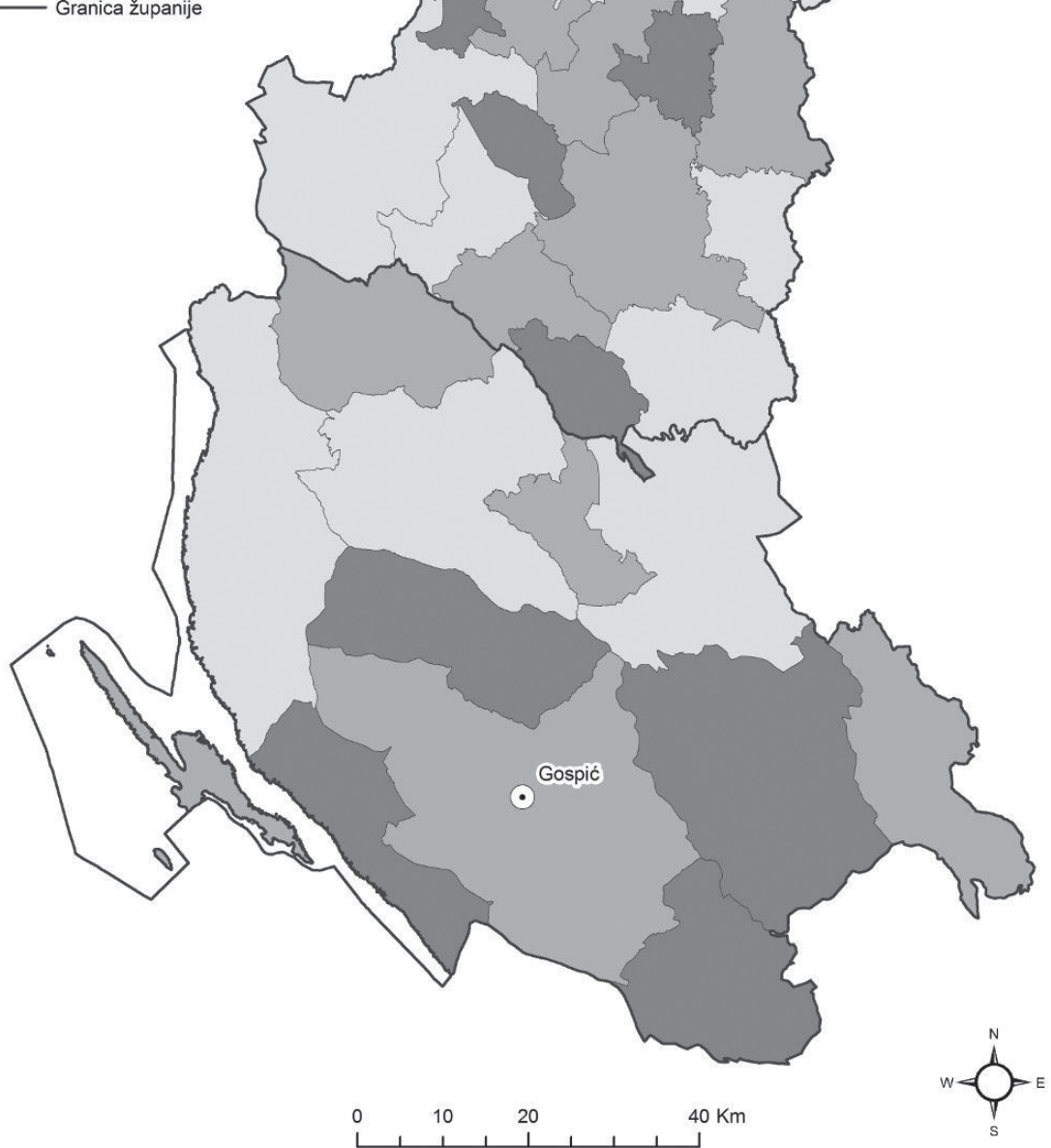

Izvor: Popis stanovništva, domaćinstava, stanova i poljoprivrednih gospodarstava 31. ožujak 1991., Stanovništvo po spolu i starosti po naseljima, dokumentacija 882, Zagreb, 1994. 
Slika 7. Tipovi ostarjelosti stanovništva u Karlovačkoj i Ličko-senjskoj županiji 2011.

Figure 7. Types of population ageing in Karlovac and Lika-Senj Counties in 2011

Tip ostarjelosti 2011.

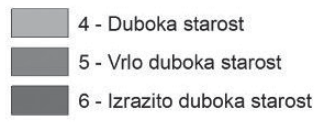

Karlovačka županija: 5 - Vrlo duboka starost

Ličko-senjska županija: 5 - Vrlo duboka starost

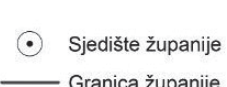

- Granica županije

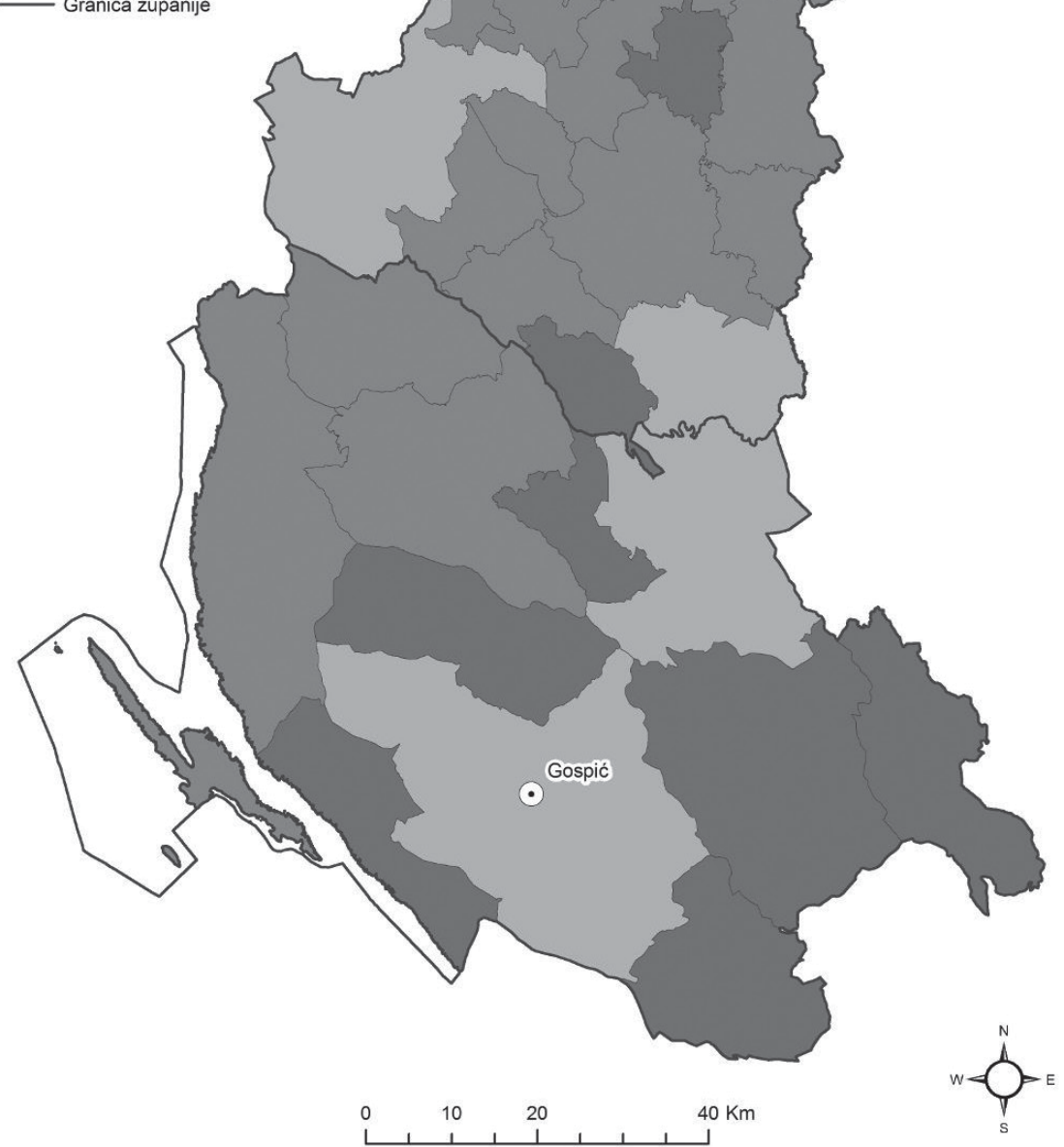

Izvor: www.dzs.hr. 
Grafički prikazi pokazuju da su obje promatrane županije u uznapredovalom stadiju ostarjelosti stanovništva. ${ }^{5}$ Domovinski rat ubrzao je intenzitet starenja stanovništva prvenstveno zbog ratom uvjetovanih migracija (Gelo, 1999). Godine 1991. Karlovačka županija imala je osjetno manju razinu ostarjelosti (tip 3 - starost) od Ličko-senjske (tip 5 - vrlo duboka starost) (slika 6). Deset godina poslije stanje se u Karlovačkoj županiji pogoršalo, te obje županije bilježe tip 5 ostarjelosti. Najnoviji popis stanovništva iz 2011. nije donio promjene $\mathrm{u}$ tipu ostarjelosti na razini županija u odnosu na prethodni popis. Razmotri li se situacija na razini gradova/općina, uviđa se značajno povećanje ostarjelosti stanovništva u razdoblju od 1991. do 2011. Očito je da doseljenici iz BiH u ovim županijama svojim brojem, ali i dobnom strukturom nisu mogli značajnije ublažiti ubrzano demografsko starenje (Gelo, 1999: 746). Istraživanje Mesića i Bagića (2007: 90) je pokazalo da su srpski povratnici ponajprije stariji ljudi, te ih je $43 \%$ starije od 60 godina.

\section{SASTAV STANOVNIŠTVA PREMA NARODNOSTI 1991.}

Sastav stanovništva prema narodnosti 1991. u obje je promatrane županije rezultat i posljedica niza povijesnih okolnosti koje dijelom datiraju još iz razdoblja ekspanzije Osmanskog Carstva na hrvatske prostore. Pred napredovanjem Osmanlija došlo do velikih migracija stanovništva. Domicilno je stanovništvo bježalo prema zapadu, Sloveniji, Austriji, Mađarskoj i Italiji, a naseljavaju se s istoka (iz osmanskih prostora) Bunjevci, etnički određeni kao Hrvati koji su bili katoličke vjeroispovijesti i takozvani Vlasi etnički određeni kao Srbi, pravoslavne vjeroispovijesti (Kaser, 1997).

Godine 1991. dva najbrojnija naroda koja su živjela u promatranim županijama bili su Hrvati i Srbi. U tabelarnom prikazu od ostalih su naroda izdvojeni samo oni čiji je udio u ukupnom stanovništvu bio $0,1 \%$ ili veći. $U$ Karlovačkoj su županiji uz Hrvate i Srbe takav udio još imali i Muslimani ${ }^{6}$, Slovenci te Jugoslaveni, dok su u Ličko-senjskoj to bili Muslimani, Albanci i Jugoslaveni. Pripadnici svih ostalih naroda, neizjašnjeni i oni čija je narodnost nepoznata svrstani su pod rubriku ostali $i$ nepoznato. Njihov je udio u ukupnoj populaciji bio 3,8\%.

U Karlovačkoj županiji Hrvati su 1991. imali najveći udio u ukupnoj populaciji $(67,4 \%)$. Udio drugoga najzastupljenijeg naroda, Srba, bio je 25,4\%

Tipizacija ostarjelosti stanovništva provedena je prema metodologiji I. Nejašmića (2005).

6 Iako postoji razlika između pojmova Musliman i Bošnjak, u ovome se radu ta dva obilježja narodnosne pripadnosti mogu analizirati zajedno. U popisu iz 1991. upotrebljavao se pojam Musliman, dok se pojam Bošnjak upotrebljavao u dva sljedeća popisa stanovništva. 
(tablica 5). Udjeli ostalih naroda zapravo su zanemarivi. Od njih se po brojnosti ističu Jugoslaveni, čiji je udio u ukupnom stanovništvu Karlovačke županije iznosio 2,2\%. Poznato je da je riječ o naciji koja je stvorena na »umjetan način « i može se pretpostaviti da su se u najvećoj mjeri Jugoslavenima izjašnjavala djeca iz brakova gdje roditelji nisu iste narodnosti (Turk, 2009).

Tablica 5. Sastav stanovništva prema narodnosti u Karlovačkoj županiji 1991.

Table 5. Ethnic structure of the population in Karlovac County in 1991

\begin{tabular}{|c|c|c|c|c|c|c|c|}
\hline $\begin{array}{l}\text { Grad/ } \\
\text { Općina }\end{array}$ & Ukupno & Hrvati & Srbi & Muslimani & Slovenci & Jugoslaveni & $\begin{array}{c}\text { Ostali i } \\
\text { nepoznato }\end{array}$ \\
\hline \multirow{2}{*}{$\begin{array}{l}\text { Grad Duga } \\
\text { Resa }\end{array}$} & 14.008 & 12.841 & 632 & 31 & 24 & 119 & 361 \\
\hline & $100 \%$ & $91,7 \%$ & $4,5 \%$ & $0,2 \%$ & $0,2 \%$ & $0,9 \%$ & $2,6 \%$ \\
\hline \multirow{2}{*}{$\begin{array}{l}\text { Grad } \\
\text { Karlovac }\end{array}$} & 73.426 & 48.202 & 17.830 & 466 & 363 & 2705 & 3860 \\
\hline & $100 \%$ & $65,7 \%$ & $24,3 \%$ & $0,6 \%$ & $0,4 \%$ & $3,7 \%$ & $5,3 \%$ \\
\hline \multirow{2}{*}{$\begin{array}{l}\text { Grad } \\
\text { Ogulin }\end{array}$} & 16.732 & 11.472 & 4329 & 39 & 25 & 416 & 451 \\
\hline & $100 \%$ & $68,6 \%$ & $25,9 \%$ & $0,2 \%$ & $0,2 \%$ & $2,4 \%$ & $2,7 \%$ \\
\hline \multirow{2}{*}{ Grad Ozalj } & 9988 & 9339 & 108 & 3 & 61 & 159 & 318 \\
\hline & $100 \%$ & $93,5 \%$ & $1,0 \%$ & $0,0 \%$ & $0,6 \%$ & $1,6 \%$ & $3,2 \%$ \\
\hline \multirow{2}{*}{ Grad Slunj } & 10.096 & 6386 & 3151 & 20 & 3 & 156 & 380 \\
\hline & $100 \%$ & $63,3 \%$ & $31,2 \%$ & $0,2 \%$ & $0,0 \%$ & $1,6 \%$ & $3,8 \%$ \\
\hline \multirow{2}{*}{$\begin{array}{l}\text { Općina } \\
\text { Barilović }\end{array}$} & 4529 & 3120 & 1272 & 1 & 1 & 9 & 126 \\
\hline & $100 \%$ & $68,9 \%$ & $28,1 \%$ & $0,0 \%$ & $0,0 \%$ & $0,2 \%$ & $2,8 \%$ \\
\hline \multirow{2}{*}{$\begin{array}{l}\text { Općina } \\
\text { Bosiljevo }\end{array}$} & 2598 & 2400 & 7 & 4 & 54 & 7 & 126 \\
\hline & $100 \%$ & $92,4 \%$ & $0,3 \%$ & $0,2 \%$ & $2,1 \%$ & $0,3 \%$ & $4,9 \%$ \\
\hline \multirow{2}{*}{$\begin{array}{l}\text { Općina } \\
\text { Cetingrad }\end{array}$} & 4758 & 2986 & 1200 & 429 & 0 & 20 & 123 \\
\hline & $100 \%$ & $62,8 \%$ & $25,2 \%$ & $9,0 \%$ & $0 \%$ & $0,4 \%$ & $2,6 \%$ \\
\hline \multirow{2}{*}{$\begin{array}{l}\text { Općina } \\
\text { Draganić }\end{array}$} & 3569 & 3348 & 46 & 16 & 2 & 19 & 138 \\
\hline & $100 \%$ & $93,8 \%$ & $1,3 \%$ & $0,5 \%$ & $0,1 \%$ & $0,5 \%$ & $3,9 \%$ \\
\hline \multirow{2}{*}{$\begin{array}{l}\text { Općina } \\
\text { Generalski } \\
\text { Stol }\end{array}$} & 3833 & 3679 & 55 & 0 & 2 & 2 & 95 \\
\hline & $100 \%$ & $96,0 \%$ & $1,4 \%$ & $0 \%$ & $0,1 \%$ & $0,1 \%$ & $2,5 \%$ \\
\hline \multirow{2}{*}{$\begin{array}{l}\text { Općina } \\
\text { Josipdol }\end{array}$} & 4850 & 3742 & 866 & 8 & 4 & 79 & 151 \\
\hline & $100 \%$ & $77,2 \%$ & $17,9 \%$ & $0,2 \%$ & $0,1 \%$ & $1,6 \%$ & $3,1 \%$ \\
\hline \multirow{2}{*}{$\begin{array}{l}\text { Općina } \\
\text { Kamanje }\end{array}$} & 1179 & 1099 & 11 & 0 & 20 & 4 & 45 \\
\hline & $100 \%$ & $93,2 \%$ & $0,1 \%$ & $0 \%$ & $1,7 \%$ & $0,3 \%$ & $3,8 \%$ \\
\hline
\end{tabular}




\begin{tabular}{|c|c|c|c|c|c|c|c|}
\hline $\begin{array}{l}\text { Grad/ } \\
\text { Općina }\end{array}$ & Ukupno & Hrvati & Srbi & Muslimani & Slovenci & Jugoslaveni & $\begin{array}{c}\text { Ostali i } \\
\text { nepoznato }\end{array}$ \\
\hline \multirow{2}{*}{$\begin{array}{l}\text { Općina } \\
\text { Krnjak }\end{array}$} & 3204 & 33 & 3091 & 2 & 2 & 25 & 51 \\
\hline & $100 \%$ & $1,0 \%$ & $96,4 \%$ & $0,1 \%$ & $0,1 \%$ & $0,8 \%$ & $1,6 \%$ \\
\hline \multirow{2}{*}{$\begin{array}{l}\text { Općina } \\
\text { Lasinja }\end{array}$} & 2821 & 1902 & 782 & 2 & 4 & 40 & 91 \\
\hline & $100 \%$ & $67,4 \%$ & $27,7 \%$ & $0,1 \%$ & $0,1 \%$ & $1,4 \%$ & $3,2 \%$ \\
\hline \multirow{2}{*}{$\begin{array}{l}\text { Općina } \\
\text { Netretić }\end{array}$} & 5437 & 5213 & 11 & 3 & 19 & 3 & 188 \\
\hline & $100 \%$ & $95,9 \%$ & $0,2 \%$ & $0,1 \%$ & $0,4 \%$ & $0,1 \%$ & $3,5 \%$ \\
\hline \multirow{2}{*}{$\begin{array}{l}\text { Općina } \\
\text { Plaški }\end{array}$} & 4317 & 83 & 4074 & 11 & 2 & 80 & 67 \\
\hline & $100 \%$ & $1,9 \%$ & $94,4 \%$ & $0,3 \%$ & $0,1 \%$ & $1,9 \%$ & $1,6 \%$ \\
\hline \multirow{2}{*}{$\begin{array}{l}\text { Općina } \\
\text { Rakovica }\end{array}$} & 4108 & 2719 & 1199 & 60 & 2 & 63 & 65 \\
\hline & $100 \%$ & $66,2 \%$ & $29,2 \%$ & $1,5 \%$ & $0,1 \%$ & $1,5 \%$ & $1,6 \%$ \\
\hline \multirow{2}{*}{$\begin{array}{l}\text { Općina } \\
\text { Ribnik }\end{array}$} & 878 & 840 & 1 & 0 & 6 & 3 & 28 \\
\hline & $100 \%$ & $95,6 \%$ & $0,1 \%$ & $0 \%$ & $0,7 \%$ & $0,3 \%$ & $3,2 \%$ \\
\hline \multirow{2}{*}{$\begin{array}{l}\text { Općina } \\
\text { Saborsko }\end{array}$} & 1501 & 801 & 658 & 0 & 0 & 0 & 42 \\
\hline & $100 \%$ & $53,4 \%$ & $43,8 \%$ & $0 \%$ & $0 \%$ & $0 \%$ & $2,8 \%$ \\
\hline \multirow{2}{*}{$\begin{array}{l}\text { Općina } \\
\text { Tounj }\end{array}$} & 1695 & 1466 & 186 & 4 & 0 & 5 & 34 \\
\hline & $100 \%$ & $86,4 \%$ & $11,0 \%$ & $0,2 \%$ & $0 \%$ & $0,3 \%$ & $2,0 \%$ \\
\hline \multirow{2}{*}{$\begin{array}{l}\text { Općina } \\
\text { Vojnić }\end{array}$} & 8236 & 116 & 7366 & 436 & 1 & 158 & 159 \\
\hline & $100 \%$ & $1,4 \%$ & $89,4 \%$ & $5,3 \%$ & $0,0 \%$ & $1,9 \%$ & $1,9 \%$ \\
\hline \multirow{2}{*}{$\begin{array}{l}\text { Općina } \\
\text { Žakanje }\end{array}$} & 2742 & 2630 & 15 & 1 & 34 & 1 & 61 \\
\hline & $100 \%$ & $95,9 \%$ & $0,6 \%$ & $0,0 \%$ & $1,2 \%$ & $0,0 \%$ & $2,2 \%$ \\
\hline \multirow{2}{*}{$\begin{array}{l}\text { Karlovačka } \\
\text { županija }\end{array}$} & 184.577 & 124.417 & 46.890 & 1536 & 629 & 4073 & 7032 \\
\hline & $100 \%$ & $67,4 \%$ & $25,4 \%$ & $0,8 \%$ & $0,3 \%$ & $2,2 \%$ & $3,8 \%$ \\
\hline
\end{tabular}

Izvor: Popis stanovništva, domaćinstava, stanova i poljoprivrednih gospodarstava 31. ožujak 1991., Narodnosni i vjerski sastav stanouništva Hrvatske 1880. - 1991. po naseljima, DZS, Zagreb, 1998.

Većina gradova i općina u sastavu Karlovačke županije, kao i županija u cijelosti, imala je 1991. apsolutnu (dvotrećinsku) većinu Hrvata. Takvi su gradovi Duga Resa, Ogulin i Ozalj te općine Barilović, Bosiljevo, Draganić, Generalski Stol, Josipdol, Kamanje, Lasinja, Netretić, Rakovica, Ribnik, Tounj i Žakanje. Natpolovičnu većinu Hrvata imali su gradovi Karlovac i Slunj te općine Cetingrad i Saborsko. Apsolutnu većinu Srba imale su općine Krnjak, Plaški i Vojnić. Najveći postotak Muslimana zabilježen je u općinama Cetingradu (9,0\%) i Vojniću (5,3\%). Takva situacija ne čudi jer se one nalaze uz granicu s Bosnom i Hercegovinom (Turk, 2009). Najveći udio Slovenaca u ukupnoj populaciji zabilježen je u Općini Bosiljevu, koja graniči sa Slo- 
venijom. Udio Jugoslavena bio je najveći $u$ dvama najvećim gradovima $u$ županiji Karlovcu i Ogulinu. Budući da su oba grada prema promatranom popisu imala značajnu srpsku narodnosnu manjinu, valja pretpostaviti da je uglavnom riječ o osobama iz takozvanih miješanih brakova gdje je jedan roditelj najčešće hrvatske, a drugi srpske narodnosti.

U Ličko-senjskoj županiji narodnosni sastav stanovništva 1991. bio je sličan onome u Karlovačkoj. Udio Hrvata u ukupnoj populaciji iznosio je $59 \%$, što je manje nego u Karlovačkoj županiji, dok je udio Srba u ukupnoj populaciji bio veći, $36,4 \%$. Ostali narodi nisu bili značajnije zastupljeni. Veći udio u ukupnoj populaciji od 0,1\% uz Hrvate i Srbe imali su još i Muslimani, Albanci i Jugoslaveni. Udio pripadnika ostalih naroda, neizjašnjenih i osoba čija narodnost nije poznata, svrstanih pod rubriku ostali $i$ nepoznato, bio je 2,8\% (tablica 6).

Tablica 6. Sastav stanovništva prema narodnosti u Ličko-senjskoj županiji 1991.

Table 6. Ethnic structure of the population in Lika-Senj County in 1991

\begin{tabular}{lccccccc}
\hline $\begin{array}{l}\text { Grad/ } \\
\text { Općina }\end{array}$ & Ukupno & Hrvati & Srbi & Muslimani & Albanci & Jugoslaveni & $\begin{array}{c}\text { Ostali i } \\
\text { nepoznato }\end{array}$ \\
\hline Grad & 22.026 & 12.796 & 7969 & 71 & 53 & 456 & 681 \\
\cline { 2 - 8 } Gospić & $100 \%$ & $58,1 \%$ & $36,2 \%$ & $0,3 \%$ & $0,2 \%$ & $2,1 \%$ & $3,1 \%$ \\
\hline Grad & 3175 & 3043 & 10 & 6 & 15 & 2 & 99 \\
\cline { 2 - 8 } Novalja & $100 \%$ & $95,8 \%$ & $0,3 \%$ & $0,2 \%$ & $0,5 \%$ & $0,1 \%$ & $3,1 \%$ \\
\hline Grad & 16.113 & 11.117 & 4469 & 19 & 19 & 106 & 383 \\
\hline Otočac & $100 \%$ & $69,0 \%$ & $27,7 \%$ & $0,1 \%$ & $0,1 \%$ & $0,7 \%$ & $2,4 \%$ \\
\hline Grad Senj & 9205 & 8549 & 207 & 30 & 36 & 27 & 356 \\
\cline { 2 - 8 } & $100 \%$ & $92,9 \%$ & $2,3 \%$ & $0,3 \%$ & $0,4 \%$ & $0,3 \%$ & $3,9 \%$ \\
\hline Općina & 6035 & 5150 & 672 & 4 & 7 & 31 & 171 \\
\hline Brinje & $100 \%$ & $85,3 \%$ & $11,1 \%$ & $0,1 \%$ & $0,1 \%$ & $0,5 \%$ & $2,8 \%$ \\
\hline Općina & 4603 & 31 & 4460 & 16 & 0 & 54 & 42 \\
\hline $\begin{array}{l}\text { Donji } \\
\text { Lapac }\end{array}$ & $100 \%$ & $0,7 \%$ & $96,9 \%$ & $0,4 \%$ & $0 \%$ & $1,2 \%$ & $0,9 \%$ \\
\hline $\begin{array}{l}\text { Općina } \\
\text { Karlobag }\end{array}$ & 1039 & 986 & 21 & 0 & 5 & 12 & 15 \\
\hline & $100 \%$ & $94,9 \%$ & $2,0 \%$ & $0 \%$ & $0,5 \%$ & $1,2 \%$ & $1,4 \%$ \\
\hline $\begin{array}{l}\text { Općina } \\
\text { Lovinac }\end{array}$ & 3054 & 1623 & 1260 & 2 & 0 & 39 & 130 \\
\hline $\begin{array}{l}\text { Općina } \\
\text { Perušić }\end{array}$ & $100 \%$ & $53,1 \%$ & $41,3 \%$ & $0,1 \%$ & $0 \%$ & $1,3 \%$ & $4,3 \%$ \\
\hline & 5648 & 4831 & 686 & 5 & 5 & 45 & 76 \\
\hline
\end{tabular}




\begin{tabular}{|c|c|c|c|c|c|c|c|}
\hline $\begin{array}{l}\text { Grad/ } \\
\text { Općina }\end{array}$ & Ukupno & Hrvati & Srbi & Muslimani & Albanci & Jugoslaveni & $\begin{array}{c}\text { Ostali i } \\
\text { nepoznato }\end{array}$ \\
\hline \multirow{2}{*}{$\begin{array}{l}\text { Općina } \\
\text { Plitvička } \\
\text { Jezera }\end{array}$} & 6765 & 1588 & 4592 & 30 & 5 & 288 & 262 \\
\hline & $100 \%$ & $23,5 \%$ & $67,9 \%$ & $0,4 \%$ & $0,1 \%$ & $4,3 \%$ & $3,9 \%$ \\
\hline \multirow{2}{*}{$\begin{array}{l}\text { Općina } \\
\text { Udbina }\end{array}$} & 4628 & 408 & 3993 & 63 & 1 & 97 & 66 \\
\hline & $100 \%$ & $8,8 \%$ & $86,3 \%$ & $1,4 \%$ & $0,0 \%$ & $2,1 \%$ & $1,4 \%$ \\
\hline \multirow{2}{*}{$\begin{array}{l}\text { Općina } \\
\text { Vrhovine }\end{array}$} & 2844 & 88 & 2640 & 3 & 0 & 46 & 67 \\
\hline & $100 \%$ & $3,1 \%$ & $92,8 \%$ & $0,1 \%$ & $0 \%$ & $1,6 \%$ & $2,4 \%$ \\
\hline \multirow{2}{*}{$\begin{array}{l}\text { Ličko- } \\
\text { senjska } \\
\text { županija }\end{array}$} & 85.135 & 50.210 & 30.979 & 249 & 146 & 1203 & 2348 \\
\hline & $100 \%$ & $59,0 \%$ & $36,4 \%$ & $0,3 \%$ & $0,2 \%$ & $1,4 \%$ & $2,8 \%$ \\
\hline
\end{tabular}

Izvor: Popis stanovništva, domaćinstava, stanova i poljoprivrednih gospodarstava 31. ožujak 1991., Narodnosni i vjerski sastav stanovništva Hrvatske 1880. - 1991. po naseljima, DZS, Zagreb,1998.

Uočljivo je da je najveća (dvotrećinska) većina Hrvata u ukupnoj populaciji zabilježena u gradovima Novalji, Otočcu i Senju te u općinama Brinju, Karlobagu i Perušiću. Natpolovična većina Hrvata zabilježena je u Gradu Gospiću i Općini Lovincu, a dvotrećinska većina Srba u ukupnom stanovništvu u općinama Donjem Lapcu, Plitvičkim Jezerima, Udbini i Vrhovinama. Značajniji udio Muslimana zabilježen je u Općini Udbini, dok je Jugoslavena bilo najviše u općinama Plitvičkim Jezerima i Udbini te u Gradu Gospiću.

\section{SASTAV STANOVNIŠTVA PREMA NARODNOSTI 2001.}

Obje županije istraživane u ovom radu bile su tijekom Domovinskog rata izložene izravnim razaranjima, a veliki dijelovi županija bili su i okupirani (Pokos, 2009). Takve su okolnosti značajno utjecale na sastav stanovništva prema narodnosti. Nakon zaposjedanja teritorija srpske su vlasti protjerivale stanovništvo koje nije bilo srpske narodnosti. Valja napomenuti da su na okupiranim prostorima vladale izrazito loša ekonomska situacija i hiperinflacija, te vrlo nepovoljna sigurnosna situacija. Budući da je taj prostor bio u zoni ratnih operacija, praktično nije bilo nikakve značajnije ekonomske djelatnosti i cijeli je okupirani prostor zapravo bio ovisan o ekonomskoj pomoći iz Srbije, a ona nije uvijek dolazila. Sve su to čimbenici koji su poticali iseljavanje Srba s tih prostora, prije svega u Srbiju i Bosnu i Hercegovinu. D. Živić (1999) je objavio procjenu broja izbjeglica iz Hrvatske u Srbiji, Crnoj Gori i Bosni i Hercegovini sredinom godina u razdoblju od 1992. do 1998. 
Godine. Iz Karlovačke županije je u ovim državama sredinom 1992. godine, temeljem te procjene bilo 7648 izbjeglica, 1993. 11.969, 1994. 12.992, 1995. 17.903, 1996. 32.205, 1997. 29.636 i 1998. 28.680. Vidljivo je da je da je najveće povećanje broja izbjeglica zabilježeno između sredine 1995. i sredine 1996. godine, zbog vojne akcije »Oluja«. Ipak, značajan je broj onih koji su izbjegli ranije, još za postojanja SAO Krajine, zbog ranije navedenih uzroka (loše ekonomske i sigurnosne situacije na okupiranim prostorima).

Tablica 7. Sastav stanovništva prema narodnosti u Karlovačkoj županiji 2001.

Table 7. Ethnic structure of the population in Karlovac County in 2001

\begin{tabular}{|c|c|c|c|c|c|c|c|}
\hline $\begin{array}{l}\text { Grad/ } \\
\text { Općina }\end{array}$ & Ukupno & Hrvati & Srbi & Albanci & Bošnjaci & Slovenci & $\begin{array}{c}\text { Ostali i } \\
\text { nepoznato }\end{array}$ \\
\hline \multirow{2}{*}{$\begin{array}{l}\text { Grad Duga } \\
\text { Resa }\end{array}$} & 12.114 & 11.642 & 220 & 21 & 7 & 10 & 214 \\
\hline & $100 \%$ & $96,1 \%$ & $1,8 \%$ & $0,2 \%$ & $0,1 \%$ & $0,1 \%$ & $1,8 \%$ \\
\hline \multirow{2}{*}{$\begin{array}{l}\text { Grad } \\
\text { Karlovac }\end{array}$} & 59.395 & 5997 & 5076 & 186 & 149 & 180 & 2807 \\
\hline & $100 \%$ & $85,9 \%$ & $8,6 \%$ & $0,3 \%$ & $0,3 \%$ & $0,3 \%$ & $4,7 \%$ \\
\hline \multirow{2}{*}{ Grad Ogulin } & 15.054 & 11.390 & 3138 & 41 & 9 & 8 & 468 \\
\hline & $100 \%$ & $75,7 \%$ & $20,8 \%$ & $0,3 \%$ & $0,1 \%$ & $0,1 \%$ & $3,1 \%$ \\
\hline \multirow{2}{*}{ Grad Ozalj } & 7932 & 7614 & 60 & 0 & 4 & 43 & 211 \\
\hline & $100 \%$ & $96,0 \%$ & $0,8 \%$ & $0 \%$ & $0,1 \%$ & $0,5 \%$ & $2,7 \%$ \\
\hline \multirow{2}{*}{ Grad Slunj } & 6096 & 5305 & 575 & 23 & 4 & 1 & 188 \\
\hline & $100 \%$ & $87,0 \%$ & $9,4 \%$ & $0,4 \%$ & $0,1 \%$ & $0,0 \%$ & $3,1 \%$ \\
\hline \multirow{2}{*}{$\begin{array}{l}\text { Općina } \\
\text { Barilović }\end{array}$} & 3095 & 2700 & 323 & 1 & 4 & 1 & 66 \\
\hline & $100 \%$ & $87,2 \%$ & $10,4 \%$ & $0,0 \%$ & $0,1 \%$ & $0,0 \%$ & $2,1 \%$ \\
\hline \multirow{2}{*}{$\begin{array}{l}\text { Općina } \\
\text { Bosiljevo }\end{array}$} & 1486 & 1435 & 4 & 2 & 4 & 31 & 10 \\
\hline & $100 \%$ & $96,6 \%$ & $0,3 \%$ & $0,1 \%$ & $0,3 \%$ & $2,1 \%$ & $0,7 \%$ \\
\hline \multirow{2}{*}{$\begin{array}{l}\text { Općina } \\
\text { Cetingrad }\end{array}$} & 2746 & 2105 & 145 & 0 & 269 & 0 & 227 \\
\hline & $100 \%$ & $76,7 \%$ & $5,3 \%$ & $0 \%$ & $9,8 \%$ & $0 \%$ & $8,3 \%$ \\
\hline \multirow{2}{*}{$\begin{array}{l}\text { Općina } \\
\text { Draganić }\end{array}$} & 2950 & 2857 & 16 & 0 & 2 & 3 & 72 \\
\hline & $100 \%$ & $96,9 \%$ & $0,5 \%$ & $0 \%$ & $0,1 \%$ & $0,1 \%$ & $2,4 \%$ \\
\hline \multirow{2}{*}{$\begin{array}{l}\text { Općina } \\
\text { Generalski } \\
\text { Stol }\end{array}$} & 3199 & 3160 & 27 & 0 & 0 & 0 & 12 \\
\hline & $100 \%$ & $98,8 \%$ & $0,8 \%$ & $0 \%$ & $0 \%$ & $0 \%$ & $0,4 \%$ \\
\hline \multirow{2}{*}{$\begin{array}{l}\text { Općina } \\
\text { Josipdol }\end{array}$} & 3987 & 3489 & 417 & 7 & 0 & 1 & 73 \\
\hline & $100 \%$ & $87,5 \%$ & $10,5 \%$ & $0,2 \%$ & $0 \%$ & $0,0 \%$ & $1,8 \%$ \\
\hline
\end{tabular}




\begin{tabular}{|c|c|c|c|c|c|c|c|}
\hline $\begin{array}{l}\text { Grad/ } \\
\text { Općina }\end{array}$ & Ukupno & Hrvati & Srbi & Albanci & Bošnjaci & Slovenci & $\begin{array}{c}\text { Ostali i } \\
\text { nepoznato }\end{array}$ \\
\hline \multirow{2}{*}{$\begin{array}{l}\text { Općina } \\
\text { Kamanje }\end{array}$} & - & - & - & - & - & - & - \\
\hline & - & - & - & - & - & - & - \\
\hline \multirow{2}{*}{$\begin{array}{l}\text { Općina } \\
\text { Krnjak }\end{array}$} & 2164 & 767 & 1332 & 0 & 1 & 1 & 63 \\
\hline & $100 \%$ & $35,4 \%$ & $61,6 \%$ & $0 \%$ & $0,1 \%$ & $0,1 \%$ & $2,9 \%$ \\
\hline \multirow{2}{*}{$\begin{array}{l}\text { Općina } \\
\text { Lasinja }\end{array}$} & 1938 & 1697 & 199 & 0 & 0 & 3 & 39 \\
\hline & $100 \%$ & $87,6 \%$ & $10,3 \%$ & $0 \%$ & $0 \%$ & $0,2 \%$ & $2,0 \%$ \\
\hline \multirow{2}{*}{$\begin{array}{l}\text { Općina } \\
\text { Netretić }\end{array}$} & 3333 & 3296 & 7 & 2 & 1 & 6 & 21 \\
\hline & $100 \%$ & $98,9 \%$ & $0,2 \%$ & $0,1 \%$ & $0,0 \%$ & $0,2 \%$ & $0,6 \%$ \\
\hline \multirow{2}{*}{$\begin{array}{l}\text { Općina } \\
\text { Plaški }\end{array}$} & 2292 & 1109 & 1054 & 6 & 2 & 0 & 121 \\
\hline & $100 \%$ & $48,4 \%$ & $46,0 \%$ & $0,3 \%$ & $0,1 \%$ & $0 \%$ & $5,3 \%$ \\
\hline \multirow{2}{*}{$\begin{array}{l}\text { Općina } \\
\text { Rakovica }\end{array}$} & 2623 & 2387 & 94 & 6 & 1 & 2 & 133 \\
\hline & $100 \%$ & $91,0 \%$ & $3,6 \%$ & $0,2 \%$ & $0,0 \%$ & $0,1 \%$ & $5,1 \%$ \\
\hline \multirow{2}{*}{$\begin{array}{l}\text { Općina } \\
\text { Ribnik }\end{array}$} & 583 & 579 & 0 & 0 & 0 & 0 & 4 \\
\hline & $100 \%$ & $99,3 \%$ & $0 \%$ & $0 \%$ & $0 \%$ & $0 \%$ & $0,7 \%$ \\
\hline \multirow{2}{*}{$\begin{array}{l}\text { Općina } \\
\text { Saborsko }\end{array}$} & 860 & 675 & 165 & 0 & 0 & 1 & 19 \\
\hline & $100 \%$ & $78,5 \%$ & $19,2 \%$ & $0 \%$ & $0 \%$ & $0,1 \%$ & $2,2 \%$ \\
\hline \multirow{2}{*}{$\begin{array}{l}\text { Općina } \\
\text { Tounj }\end{array}$} & 1252 & 1206 & 35 & 0 & 0 & 0 & 11 \\
\hline & $100 \%$ & $96,3 \%$ & $2,8 \%$ & $0 \%$ & $0 \%$ & $0 \%$ & $0,9 \%$ \\
\hline \multirow{2}{*}{$\begin{array}{l}\text { Općina } \\
\text { Vojnić }\end{array}$} & 5495 & 1980 & 2747 & 1 & 435 & 1 & 331 \\
\hline & $100 \%$ & $36,0 \%$ & $50,0 \%$ & $0,0 \%$ & $7,9 \%$ & $0,0 \%$ & $6,0 \%$ \\
\hline \multirow{2}{*}{$\begin{array}{l}\text { Opć́ina } \\
\text { Žakanje }\end{array}$} & 3193 & 3100 & 17 & 4 & 0 & 44 & 28 \\
\hline & $100 \%$ & $97,1 \%$ & $0,5 \%$ & $0,1 \%$ & $0 \%$ & $1,4 \%$ & $0,9 \%$ \\
\hline \multirow{2}{*}{$\begin{array}{l}\text { Karlovačka } \\
\text { županija }\end{array}$} & 141.787 & 119.490 & 15.651 & 300 & 892 & 340 & 5114 \\
\hline & $100 \%$ & $84,3 \%$ & $11,0 \%$ & $0,2 \%$ & $0,6 \%$ & $0,2 \%$ & $3,6 \%$ \\
\hline
\end{tabular}

Izvor: Popis stanovništva 2001., www.dzs.hr.

Razmotri li se stanje u Karlovačkoj županiji, može se zaključiti da je na razini županije kao i na razini gradova/općina došlo do homogenizacije u narodnosnom sastavu stanovništva u smislu povećanja udjela Hrvata kao većinskog naroda i smanjenja udjela Srba. Udio Hrvata povećao se sa 67,4\% na $84,3 \%$, dok se udio Srba smanjio s $25,4 \%$ na $11,0 \%$ (tablica 7 ). Najveći se broj Srba s promatranog prostora iselio, odnosno izbjegao početkom hrvatske vojno-redarstvene operacije »Oluja« početkom kolovoza 1995., pred naletom hrvatskih snaga koje su oslobodile okupirane prostore (Turk, 2009). Većina njih nije se vratila do popisa 2001. Povećanje udjela Hrvata, 
poglavito u prostorima gdje oni prije Domovinskog rata nisu imali dvotrećinsku većinu, dijelom je posljedica useljavanja prognanih Hrvata iz Bosne i Hercegovine (Republike Srpske), a dijelom selektivne emigracije srpskog stanovništva.

Raspadom Jugoslavije nestaju i Jugoslaveni kao narodnost, no povećava se udio Albanaca, koje se, s udjelom od 0,2\%, za razliku od prošlog popisa, sada promatra posebno, tj. izdvojeni su iz skupine ostali i nepoznato.

Hrvati su imali apsolutnu većinu ( $\geq 2 / 3$ u ukupnom stanovništvu) u županiji promatranoj u cijelosti kao i u svim gradovima/općinama osim u općinama Krnjaku, Plaškom i Vojniću. U Općini Krnjaku natpolovična većina stanovništva bila je srpske narodnosti (61,6\%). U Općini Vojniću Srbi su imali udio od 50,0\%, dok su u Općini Plaškom Hrvati imali udio od 48,4\%, a Srbi $46,0 \%$.

Bošnjaci su bili treća najzastupljenija narodnosna manjina u Ličko-senjskoj županiji, a najviše ih je bilo u općinama Cetingradu (9,8\%) i Vojniću (7,9\%). U Općini Cetingradu povećanje udjela Bošnjaka zanemarivo je, dok je ono u Općini Vojniću nešto izraženije. Uzrok je toga povećanja u najvećoj mjeri imigracija iz susjedne Bosne i Hercegovine. Prema popisu stanovništva iz 1991., u Općini Vojniću živjelo je 535 stanovnika doseljenih iz stranih država koje su nastale raspadom bivše Jugoslavije. Sljedeći popis iz 2001. u Općini Vojniću bilježi 1935 osoba doseljenih iz Bosne i Hercegovine.

U Ličko-senjskoj županiji došlo je do sličnih promjena u narodnosnom sastavu stanovništva. Udio Hrvata povećao se s 59,0 na $86,2 \%$, dok se udio Srba smanjio s $36,4 \%$ na $11,5 \%$ (tablica 8 ). Jugoslaveni su i ovdje nestali kao narodnost, a udio u ukupnom stanovništvu od $0,1 \%$ ili veći uz Hrvate i Srbe imali su jedino Albanci i Bošnjaci.

Tablica 8. Sastav stanovništva prema narodnosti u Ličko-senjskoj županiji 2001.

Table 8. Ethnic structure of the population in Lika-Senj County in 2001

\begin{tabular}{lcccccc}
\hline Grad/Općina & Ukupno & Hrvati & Srbi & Albanci & Bošnjaci & $\begin{array}{c}\text { Ostali i } \\
\text { nepoznato }\end{array}$ \\
\hline \multirow{2}{*}{ Grad Gospić } & 12.980 & 12.050 & 625 & 28 & 32 & 245 \\
\cline { 2 - 7 } & $100 \%$ & $92,8 \%$ & $4,8 \%$ & $0,2 \%$ & $0,3 \%$ & $1,9 \%$ \\
\hline \multirow{2}{*}{ Grad Novalja } & 3335 & 3230 & 14 & 33 & 11 & 47 \\
\cline { 2 - 7 } & $100 \%$ & $96,9 \%$ & $0,4 \%$ & $1,0 \%$ & $0,3 \%$ & $1,4 \%$ \\
\hline \multirow{2}{*}{ Grad Otočac } & 10.411 & 9504 & 690 & 4 & 4 & 209 \\
\cline { 2 - 7 } & $100 \%$ & $91,3 \%$ & $6,6 \%$ & $0,0 \%$ & $0,0 \%$ & $2,0 \%$ \\
\hline
\end{tabular}




\begin{tabular}{|c|c|c|c|c|c|c|}
\hline Grad/Općina & Ukupno & Hrvati & Srbi & Albanci & Bošnjaci & $\begin{array}{c}\text { Ostali i } \\
\text { nepoznato }\end{array}$ \\
\hline \multirow{2}{*}{ Grad Senj } & 8132 & 7869 & 92 & 23 & 8 & 140 \\
\hline & $100 \%$ & $96,8 \%$ & $1,1 \%$ & $0,3 \%$ & $0,1 \%$ & $1,7 \%$ \\
\hline \multirow{2}{*}{ Općina Brinje } & 4108 & 3760 & 319 & 1 & 0 & 28 \\
\hline & $100 \%$ & $91,5 \%$ & $7,8 \%$ & $0,0 \%$ & $0 \%$ & $0,7 \%$ \\
\hline \multirow{2}{*}{$\begin{array}{l}\text { Općina Donji } \\
\text { Lapac }\end{array}$} & 1880 & 471 & 1383 & 0 & 0 & 26 \\
\hline & $100 \%$ & $25,1 \%$ & $73,6 \%$ & $0 \%$ & $0 \%$ & $1,4 \%$ \\
\hline \multirow{2}{*}{$\begin{array}{l}\text { Općina } \\
\text { Karlobag }\end{array}$} & 1019 & 942 & 10 & 1 & 14 & 52 \\
\hline & $100 \%$ & $92,4 \%$ & $1,0 \%$ & $0,1 \%$ & $1,4 \%$ & $5,1 \%$ \\
\hline \multirow{2}{*}{$\begin{array}{l}\text { Općina } \\
\text { Lovinac }\end{array}$} & 1096 & 986 & 89 & 0 & 0 & 21 \\
\hline & $100 \%$ & $90,0 \%$ & $8,1 \%$ & $0 \%$ & $0 \%$ & $1,9 \%$ \\
\hline \multirow{2}{*}{$\begin{array}{l}\text { Općina } \\
\text { Perušić }\end{array}$} & 3494 & 3103 & 334 & 5 & 2 & 50 \\
\hline & $100 \%$ & $88,8 \%$ & $9,6 \%$ & $0,1 \%$ & $0,1 \%$ & $1,4 \%$ \\
\hline \multirow{2}{*}{$\begin{array}{l}\text { Općina } \\
\text { Plitvička } \\
\text { Jezera }\end{array}$} & 4668 & 3141 & 1424 & 12 & 2 & 89 \\
\hline & $100 \%$ & $67,3 \%$ & $30,5 \%$ & $0,3 \%$ & $0,0 \%$ & $1,9 \%$ \\
\hline \multirow{2}{*}{$\begin{array}{l}\text { Općina } \\
\text { Udbina }\end{array}$} & 1649 & 841 & 715 & 0 & 15 & 78 \\
\hline & $100 \%$ & $51,0 \%$ & $43,4 \%$ & $0 \%$ & $0,9 \%$ & $4,7 \%$ \\
\hline \multirow{2}{*}{$\begin{array}{l}\text { Općina } \\
\text { Vrhovine }\end{array}$} & 905 & 348 & 498 & 3 & 0 & 56 \\
\hline & $100 \%$ & $38,5 \%$ & $55,0 \%$ & $0,3 \%$ & $0 \%$ & $6,2 \%$ \\
\hline \multirow{2}{*}{$\begin{array}{l}\text { Ličko- } \\
\text { senjska } \\
\text { županija }\end{array}$} & 53.677 & 46.245 & 6139 & 110 & 88 & 1095 \\
\hline & $100 \%$ & $86,2 \%$ & $11,5 \%$ & $0,2 \%$ & $0,2 \%$ & $2,0 \%$ \\
\hline
\end{tabular}

Izvor: Popis stanovništva 2001., wwww.dzs.hr.

U Gradu Gospiću i Općini Lovincu Hrvati su 1991. imali natpolovičnu većinu u ukupnom stanovništvu. Deset godina poslije taj se udio osjetno povećao. Općine Plitvička Jezera i Udbina imale su 1991. većinski udio Srba u ukupnom stanovništvu. Popis iz 2001. pokazuje da je većina stanovništva bila hrvatske narodnosti. U Općini Vrhovinama Srbi su 1991. imali apsolutnu većinu u ukupnom stanovništvu. Deset godina poslije Srbi su u toj općini i dalje bili većinski narod, no njihov je udio bio tek 55,0\%. U svim trima općinama (Plitvička Jezera, Udbina i Vrhovine) povećao se udio Hrvata. U Općini Donjem Lapcu Srbi su i 2001. činili većinu stanovništva, s time da im je udio bio osjetno manji nego 1991., dok se udio Hrvata povećao. Dogodila se ista situacija kao i u Karlovačkoj županiji. Najveći je dio Srba izbjegao u Srbiju i Bosnu i Hercegovinu početkom hrvatske vojno-redarstvene operacije »Oluja«. Prema procjeni D. Živića (1999), broj izbjeglica iz Ličko-senjske 
županije u Srbiji, Crnoj Gori i Bosni i Hercegovini sredinom 1992. godine iznosio je 8520. Sredinom 1993. njihov broj raste i iznosi 13.338, 1994. 14.478, 1995. 19.950, 1996. 35.861, 1997. 33.015, te 1998. 31.950. I ovdje je vidljivo da je u razdoblju od sredine 1995. do sredine 1996. broj izbjeglica jako porastao što je posljedica zbjega Srba. Međutim i ovdje je prisutno znatno iseljavanje ranijih godina koje je potaknuto lošim ekonomskim i sigurnosnim čimbenicima na tada okupiranim područjima. Po oslobođenju okupiranih prostora na dio ispražnjenog prostora naseljavaju se prognani Hrvati iz susjedne Bosne i Hercegovine.

U gradovima i općinama koji nisu spomenuti nije bilo značajnije promjene $\mathrm{u}$ narodnosnom sastavu stanovništva. Isto vrijedi i za udjele Albanaca i Bošnjaka.

Može se zaključiti da su promjene u narodnosnom sastavu stanovništva Karlovačke i Ličko-senjske županije u međupopisju 1991. - 2001. ponajprije uvjetovane zbivanjima povezanim s Domovinskim ratom i ratnim zbivanjima u susjednoj Bosni i Hercegovini.

\section{SASTAV STANOVNIŠTVA PREMA NARODNOSTI 2011.}

U sljedećemu međupopisju 2001. - 2011. nije bilo toliko izraženih promjena u narodnosnom sastavu stanovništva Karlovačke i Ličko-senjske županije kao u prethodnome razdoblju. To je razumljivo jer $\mathrm{u}$ tom razdoblju (2001. - 2011.) nije bilo ratnih zbivanja, koja su u prethodnome međupopisju imala najznačajniji utjecaj na promjene u narodnosnom sastavu stanovništva.

Tablica 9. Sastav stanovništva prema narodnosti u Karlovačkoj županiji 2011.

Table 9. Ethnic structure of the population in Karlovac County in 2011

\begin{tabular}{lccccccc}
\hline $\begin{array}{l}\text { Grad/ } \\
\text { Općina }\end{array}$ & Ukupno & Hrvati & Srbi & Albanci & Bošnjaci & Slovenci $\begin{array}{c}\text { Ostali i } \\
\text { nepoznato }\end{array}$ \\
\hline Grad Duga & 11.180 & 10.888 & 187 & 25 & 11 & 3 & 66 \\
\cline { 2 - 7 } Resa & $100 \%$ & $97,4 \%$ & $1,7 \%$ & $0,2 \%$ & $0,1 \%$ & $0,0 \%$ & $0,6 \%$ \\
\hline Grad & 55.705 & 49.140 & 4460 & 237 & 250 & 128 & 1490 \\
\cline { 2 - 7 } Karlovac & $100 \%$ & $88,2 \%$ & $8,0 \%$ & $0,4 \%$ & $0,5 \%$ & $0,2 \%$ & $2,7 \%$ \\
\hline Grad Ogulin & 13.915 & 11.159 & 2466 & 20 & 14 & 8 & 248 \\
\hline & $100 \%$ & $80,2 \%$ & $17,7 \%$ & $0,1 \%$ & $0,1 \%$ & $0,1 \%$ & $1,8 \%$ \\
\hline
\end{tabular}


Grad/

Općina

Ukupno Hrvat

Srbi Albanci Bošnjaci Slovenci Ostali i

\begin{tabular}{|c|c|c|c|c|c|c|c|}
\hline \multirow{2}{*}{ Grad Ozalj } & 6817 & 6604 & 64 & 4 & 7 & 35 & 103 \\
\hline & $100 \%$ & $96,9 \%$ & $0,9 \%$ & $0,1 \%$ & $0,1 \%$ & $0,5 \%$ & $1,5 \%$ \\
\hline \multirow{2}{*}{ Grad Slunj } & 5076 & 4463 & 534 & 25 & 10 & 3 & 41 \\
\hline & $100 \%$ & $87,9 \%$ & $10,5 \%$ & $0,5 \%$ & $0,2 \%$ & $0,1 \%$ & $0,8 \%$ \\
\hline \multirow{2}{*}{$\begin{array}{l}\text { Općina } \\
\text { Barilović }\end{array}$} & 2990 & 2610 & 354 & 1 & 7 & 1 & 17 \\
\hline & $100 \%$ & $87,3 \%$ & $11,8 \%$ & $0,0 \%$ & $0,2 \%$ & $0,0 \%$ & $0,6 \%$ \\
\hline \multirow{2}{*}{$\begin{array}{l}\text { Općina } \\
\text { Bosiljevo }\end{array}$} & 1284 & 1246 & 4 & 1 & 1 & 24 & 8 \\
\hline & $100 \%$ & $97,0 \%$ & $0,3 \%$ & $0,1 \%$ & $0,1 \%$ & $1,9 \%$ & $0,6 \%$ \\
\hline \multirow{2}{*}{$\begin{array}{l}\text { Općina } \\
\text { Cetingrad }\end{array}$} & 2027 & 1510 & 101 & 0 & 314 & 0 & 102 \\
\hline & $100 \%$ & $74,5 \%$ & $5,0 \%$ & $0 \%$ & $15,5 \%$ & $0 \%$ & $5,0 \%$ \\
\hline \multirow{2}{*}{$\begin{array}{l}\text { Općina } \\
\text { Draganić }\end{array}$} & 2741 & 2630 & 11 & 0 & 14 & 3 & 83 \\
\hline & $100 \%$ & $96,0 \%$ & $0,4 \%$ & $0 \%$ & $0,5 \%$ & $0,1 \%$ & $3,0 \%$ \\
\hline \multirow{2}{*}{$\begin{array}{l}\text { Općina } \\
\text { Generalski } \\
\text { Stol }\end{array}$} & 2642 & 2619 & 16 & 0 & 0 & 1 & 6 \\
\hline & $100 \%$ & $99,1 \%$ & $0,6 \%$ & $0 \%$ & $0 \%$ & $0,0 \%$ & $0,2 \%$ \\
\hline \multirow{2}{*}{$\begin{array}{l}\text { Općina } \\
\text { Josipdol }\end{array}$} & 3773 & 3404 & 326 & 5 & 2 & 2 & 34 \\
\hline & $100 \%$ & $90,2 \%$ & $8,6 \%$ & $0,1 \%$ & $0,1 \%$ & $0,1 \%$ & $0,9 \%$ \\
\hline \multirow{2}{*}{$\begin{array}{l}\text { Općina } \\
\text { Kamanje }\end{array}$} & 891 & 871 & 4 & 3 & 0 & 10 & 3 \\
\hline & $100 \%$ & $97,8 \%$ & $0,5 \%$ & $0,3 \%$ & $0 \%$ & $1,1 \%$ & $0,3 \%$ \\
\hline \multirow{2}{*}{$\begin{array}{l}\text { Općina } \\
\text { Krnjak }\end{array}$} & 1985 & 579 & 1362 & 4 & 10 & 0 & 30 \\
\hline & $100 \%$ & $29,2 \%$ & $68,6 \%$ & $0,2 \%$ & $0,5 \%$ & $0 \%$ & $1,5 \%$ \\
\hline \multirow{2}{*}{$\begin{array}{l}\text { Općina } \\
\text { Lasinja }\end{array}$} & 1624 & 1406 & 192 & 0 & 1 & 3 & 22 \\
\hline & $100 \%$ & $86,6 \%$ & $11,8 \%$ & $0 \%$ & $0,1 \%$ & $0,2 \%$ & $1,4 \%$ \\
\hline \multirow{2}{*}{$\begin{array}{l}\text { Općina } \\
\text { Netretić }\end{array}$} & 2862 & 2835 & 8 & 1 & 0 & 8 & 10 \\
\hline & $100 \%$ & $99,1 \%$ & $0,3 \%$ & $0,0 \%$ & $0 \%$ & $0,3 \%$ & $0,4 \%$ \\
\hline \multirow{2}{*}{$\begin{array}{l}\text { Općina } \\
\text { Plaški }\end{array}$} & 2090 & 1074 & 952 & 3 & 2 & 3 & 56 \\
\hline & $100 \%$ & $51,4 \%$ & $45,6 \%$ & $0,1 \%$ & $0,1 \%$ & $0,1 \%$ & $2,7 \%$ \\
\hline \multirow{2}{*}{$\begin{array}{l}\text { Općina } \\
\text { Rakovica }\end{array}$} & 2387 & 2262 & 77 & 0 & 23 & 1 & 24 \\
\hline & $100 \%$ & $94,8 \%$ & $3,2 \%$ & $0 \%$ & $1,0 \%$ & $0 \%$ & $1,0 \%$ \\
\hline \multirow{2}{*}{$\begin{array}{l}\text { Općina } \\
\text { Ribnik }\end{array}$} & 475 & 469 & 0 & 0 & 0 & 5 & 1 \\
\hline & $100 \%$ & $98,7 \%$ & $0 \%$ & $0 \%$ & $0 \%$ & $1,1 \%$ & $0,2 \%$ \\
\hline \multirow{2}{*}{$\begin{array}{l}\text { Općina } \\
\text { Saborsko }\end{array}$} & 632 & 489 & 136 & 0 & 0 & 0 & 7 \\
\hline & $100 \%$ & $77,4 \%$ & $21,5 \%$ & $0 \%$ & $0 \%$ & $0 \%$ & $1,1 \%$ \\
\hline \multirow{2}{*}{$\begin{array}{l}\text { Općina } \\
\text { Tounj }\end{array}$} & 1150 & 1127 & 20 & 0 & 1 & 1 & 1 \\
\hline & $100 \%$ & $98,0 \%$ & $1,7 \%$ & $0 \%$ & $0,1 \%$ & $0,1 \%$ & $0,1 \%$ \\
\hline
\end{tabular}




\begin{tabular}{lccccccc}
\hline $\begin{array}{l}\text { Grad/ } \\
\text { Općina }\end{array}$ & Ukupno & Hrvati & Srbi & Albanci & Bošnjaci & Slovenci & $\begin{array}{c}\text { Ostali i } \\
\text { nepoznato }\end{array}$ \\
\hline $\begin{array}{l}\text { Općina } \\
\text { Vojnić }\end{array}$ & 4764 & 1769 & 2130 & 11 & 318 & 1 & 535 \\
\cline { 2 - 8 } & $100 \%$ & $37,1 \%$ & $44,7 \%$ & $0,2 \%$ & $6,7 \%$ & $0,0 \%$ & $11,2 \%$ \\
\hline $\begin{array}{l}\text { Općina } \\
\text { Žakanje }\end{array}$ & 1889 & 1842 & 4 & 0 & 1 & 37 & 5 \\
\cline { 2 - 8 } & $100 \%$ & $97,5 \%$ & $0,2 \%$ & $0 \%$ & $0,1 \%$ & $2,0 \%$ & $0,3 \%$ \\
\hline $\begin{array}{l}\text { Karlovačka } \\
\text { županija }\end{array}$ & $\mathbf{1 2 8 . 8 9 9}$ & $\mathbf{1 1 0 . 9 9 6}$ & $\mathbf{1 3 . 4 0 8}$ & $\mathbf{3 4 0}$ & $\mathbf{9 8 6}$ & $\mathbf{2 7 7}$ & $\mathbf{2 8 9 2}$ \\
\hline
\end{tabular}

Izvor: Popis stanovništva 2011., www.dzs.hr.

Iako se može zaključiti da od 2001. do 2011. nije došlo do značajnijih promjena u sastavu stanovništva prema narodnosti u Karlovačkoj županiji, uočljivo je malo povećanje udjela Hrvata u ukupnom stanovništvu županije (tablica 9). Taj je proces prisutan i u većem dijelu gradova i općina. Udio Srba prema popisu iz 2011. bio je neznatno manji od onoga iz prethodnog popisa. Ipak, u Općini Krnjaku, koja je jedina u Karlovačkoj županiji imala većinu srpskog stanovništva, u ovom je međupopisju zabilježen porast udjela Srba (sa 61,6\% na 68,6\%). Kako ne postoje podaci o migraciji stanovništva prema narodnosnom sastavu (Lajić, 2002), valja pretpostaviti da je riječ o djelomičnom povratku izbjeglih Srba s jedne strane i povratničkim tokovima Hrvata koji su bili protjerani iz Bosne i Hercegovine s druge strane.

Zanimljiv je i porast udjela Bošnjaka u Općini Cetingradu s 9,8\% u 2001. na 15,5\% u 2011. Može se pretpostaviti da su posrijedi imigracijski tokovi Bošnjaka iz Bosne i Hercegovine i istovremena emigracija Hrvata, jer je udio Hrvata smanjen sa 76,7\% u 2001. na 74,5\% u 2011.

Tablica 10. Sastav stanovništva prema narodnosti u Ličko-senjskoj županiji 2011.

Table 10. Ethnic structure of the population in Lika-Senj County in 2011

\begin{tabular}{lccccccc}
\hline $\begin{array}{l}\text { Grad/ } \\
\text { Općina }\end{array}$ & Ukupno & Hrvati & Srbi & Albanci & Bošnjaci $\begin{array}{c}\text { Izjasnili } \\
\text { se u } \\
\text { vjerskom } \\
\text { smislu }\end{array}$ & $\begin{array}{c}\text { Ostali i } \\
\text { nepoznato }\end{array}$ \\
\hline Grad Gospić & 12.745 & 11.860 & 609 & 54 & 49 & 55 & 118 \\
\cline { 2 - 8 } & $100 \%$ & $93,1 \%$ & $4,8 \%$ & $0,4 \%$ & $0,4 \%$ & $0,4 \%$ & $0,9 \%$ \\
\hline $\begin{array}{l}\text { Grad } \\
\text { Novalja }\end{array}$ & 3663 & 3523 & 22 & 41 & 24 & 2 & 51 \\
\hline & $100 \%$ & $96,2 \%$ & $0,6 \%$ & $1,1 \%$ & $0,7 \%$ & $0,1 \%$ & $1,4 \%$ \\
\hline
\end{tabular}




\begin{tabular}{|c|c|c|c|c|c|c|c|}
\hline $\begin{array}{l}\text { Grad/ } \\
\text { Općina }\end{array}$ & Ukupno & Hrvati & Srbi & Albanci & Bošnjaci & $\begin{array}{c}\text { Izjasnili } \\
\text { se u } \\
\text { vjerskom } \\
\text { smislu } \\
\end{array}$ & $\begin{array}{c}\text { Ostali i } \\
\text { nepoznato }\end{array}$ \\
\hline \multirow{2}{*}{ Grad Otočac } & 9778 & 8916 & 709 & 13 & 14 & 5 & 121 \\
\hline & $100 \%$ & $91,2 \%$ & $7,3 \%$ & $0,1 \%$ & $0,1 \%$ & $0,1 \%$ & $1,3 \%$ \\
\hline \multirow{2}{*}{ Grad Senj } & 7182 & 6971 & 66 & 27 & 24 & 3 & 91 \\
\hline & $100 \%$ & $97,1 \%$ & $0,9 \%$ & $0,4 \%$ & $0,3 \%$ & $0,0 \%$ & $1,3 \%$ \\
\hline \multirow{2}{*}{$\begin{array}{l}\text { Općina } \\
\text { Brinje }\end{array}$} & 3256 & 3024 & 194 & 2 & 4 & 3 & 29 \\
\hline & $100 \%$ & $92,9 \%$ & $6,0 \%$ & $0,1 \%$ & $0,1 \%$ & $0,1 \%$ & $0,9 \%$ \\
\hline \multirow{2}{*}{$\begin{array}{l}\text { Općina Donji } \\
\text { Lapac }\end{array}$} & 2113 & 397 & 1704 & 0 & 2 & 2 & 8 \\
\hline & $100 \%$ & $18,8 \%$ & $80,6 \%$ & $0 \%$ & $0,1 \%$ & $0,1 \%$ & $0,4 \%$ \\
\hline \multirow{2}{*}{$\begin{array}{l}\text { Općina } \\
\text { Karlobag }\end{array}$} & 917 & 865 & 9 & 8 & 7 & 7 & 21 \\
\hline & $100 \%$ & $94,3 \%$ & $1,0 \%$ & $0,9 \%$ & $0,8 \%$ & $0,8 \%$ & $2,3 \%$ \\
\hline \multirow{2}{*}{$\begin{array}{l}\text { Općina } \\
\text { Lovinac }\end{array}$} & 1007 & 835 & 162 & 0 & 1 & 5 & 4 \\
\hline & $100 \%$ & $82,9 \%$ & $16,1 \%$ & $0 \%$ & $0,1 \%$ & $0,5 \%$ & $0,4 \%$ \\
\hline \multirow{2}{*}{$\begin{array}{l}\text { Općina } \\
\text { Perušić }\end{array}$} & 2638 & 2380 & 224 & 5 & 5 & 12 & 12 \\
\hline & $100 \%$ & $90,2 \%$ & $8,5 \%$ & $0,2 \%$ & $0,2 \%$ & $0,5 \%$ & $0,5 \%$ \\
\hline \multirow{2}{*}{$\begin{array}{l}\text { Općina } \\
\text { Plitvička } \\
\text { Jezera }\end{array}$} & 4373 & 3066 & 1184 & 14 & 20 & 18 & 71 \\
\hline & $100 \%$ & $70,1 \%$ & $27,1 \%$ & $0,3 \%$ & $0,5 \%$ & $0,4 \%$ & $1,6 \%$ \\
\hline \multirow{2}{*}{$\begin{array}{l}\text { Općina } \\
\text { Udbina }\end{array}$} & 1874 & 844 & 958 & 1 & 18 & 19 & 34 \\
\hline & $100 \%$ & $45,0 \%$ & $51,1 \%$ & $0,1 \%$ & $1,0 \%$ & $1,0 \%$ & $1,8 \%$ \\
\hline \multirow{2}{*}{$\begin{array}{l}\text { Općina } \\
\text { Vrhovine }\end{array}$} & 1381 & 176 & 1108 & 6 & 0 & 7 & 84 \\
\hline & $100 \%$ & $12,7 \%$ & $80,2 \%$ & $0,4 \%$ & $0 \%$ & $0,5 \%$ & $6,1 \%$ \\
\hline \multirow{2}{*}{$\begin{array}{l}\text { Ličko- } \\
\text { senjska } \\
\text { županija }\end{array}$} & 50.927 & 42.857 & 6949 & 171 & 168 & 138 & 644 \\
\hline & $100 \%$ & $84,2 \%$ & $13,7 \%$ & $0,3 \%$ & $0,3 \%$ & $0,3 \%$ & $1,3 \%$ \\
\hline
\end{tabular}

Izvor: Popis stanovništva 2011., www.dzs.hr.

Situacija u Ličko-senjskoj županiji drukčija je od one u Karlovačkoj. Ovdje je u međupopisju od 2001. do 2011. došlo do blagog smanjenja udjela Hrvata (s $86,2 \%$ na $84,2 \%$ ) i povećanja udjela Srba s $11,5 \%$ na $13,7 \%$ (tablica 10). Budući da ne postoje podaci o migraciji po narodnosti, valja pretpostaviti da je takvo stanje rezultat povratka izbjeglih Srba iz Srbije i Bosne i Hercegovine te djelomičnog povratka Hrvata protjeranih iz Bosne i Hercegovine svojim domovima. U većini općina nije bilo veće promjene u sastavu stanovništva prema narodnosti. Najizraženija je promjena zabilježena u Općini Vrhovinama, gdje se udio Srba povećao s 55,0\% na 80,2\%. Zanimlji- 
vo je da je 2011. udio stanovnika koji su se prema narodnosti izjasnili u vjerskom smislu bio veći od $0,1 \%$, pa je ta kategorija uvrštena (tablica 10). Udio takva stanovništva bio je $0,3 \%$ što se vjerojatno može pripisati stanovništvu islamske vjeroispovijesti koje se izjasnilo kao Muslimani. Udio stanovnika koji potpadaju pod kategoriju ostali i nepoznato bio je 2011. neuobičajeno visok u Općini Vrhovinama: čak 76 stanovnika (5,5\%) nije se izjasnilo prema narodnosnoj pripadnosti.

Može se zaključiti da su promjene u narodnosnom sastavu stanovništvu Karlovačke i Ličko-senjske županije od 2001. do 2011. bile osjetno manje od onih u prošlome međupopisju. S izuzetkom onih općina gdje je zabilježen značajniji povratak Srba, nije bilo značajnijih promjena u narodnosnim sastavima promatranih županija.

Na kartodijagramu je prikazana promjena u postocima dvaju najzastupljenijih naroda, Hrvata i Srba, u Karlovačkoj županiji od 1991. do 2011. (slika 8). Budući da su sve ostale narodnosti zastupljene malim udjelom, one su zajedno s neizjašnjenima i osobama nepoznate narodnosti svrstane u kategoriju ostalo. Vezano uz promjenu narodnosnog sastava stanovništva Karlovačke županije mogu se izdvojiti dvije skupine gradova i općina. Prvu tvore oni gradovi odnosno općine koji tijekom Domovinskog rata nisu bili okupirani te sukladno tome nisu zabilježili veće promjene u narodnosnom sastavu stanovništva. Takvi su gradovi/općine locirani u zapadnom dijelu županije: gradovi Duga Resa, Ogulin i Ozalj, te općine Bosiljevo, Draganić, Generalski Stol, Kamanje, Netretić, Ribnik i Žakanje. Drugu skupinu tvore gradovi/općine čiji su dijelovi teritorija ili cijeli teritoriji bili okupirani tijekom Domovinskog rata i u kojima su se zbog ratnih zbivanja dogodile znatne promjene narodnosnog sastava stanovništva. To su gradovi Karlovac i Slunj, te općine Barilović, Cetingrad, Josipdol, Krnjak, Lasinja, Plaški, Saborsko, Rakovica, Tounj i Vojnić. Slična je situacija i u Ličko-senjskoj županiji. I u ovoj županiji oni gradovi/općine koji su tijekom Domovinskog rata bili okupirani zabilježili značajnu promjenu u narodnosnom sastavu stanovništva. Gradovi Senj, Novalja i općina Karlobag koji nisu bile izravno zahvaćeni ratnim sukobima bilježe osjetno manju promjenu u narodnosnom sastavu stanovništva. 
Slika 8. Promjene u sastavu stanovništva prema narodnosti u Karlovačkoj županiji 1991. - 2011.

Figure 8. Changes in the ethnic structure of the population in Karlovac County, 1991-2011

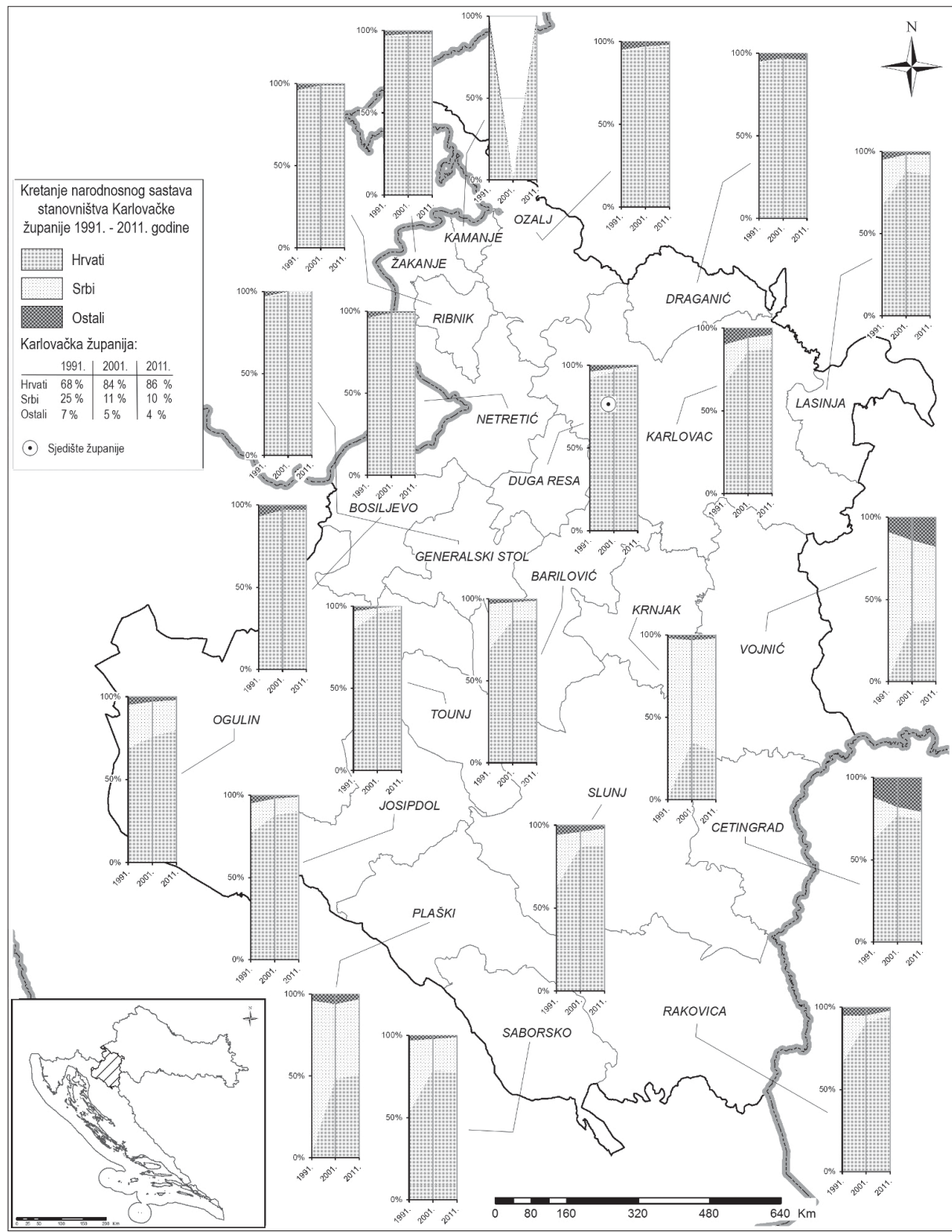


Slika 9. Promjene u sastavu stanovništva prema narodnosti u Ličkosenjskoj županiji 1991. - 2011.

Figure 9. Changes in the ethnic structure of the population in Lika-Senj County, 1991-2011

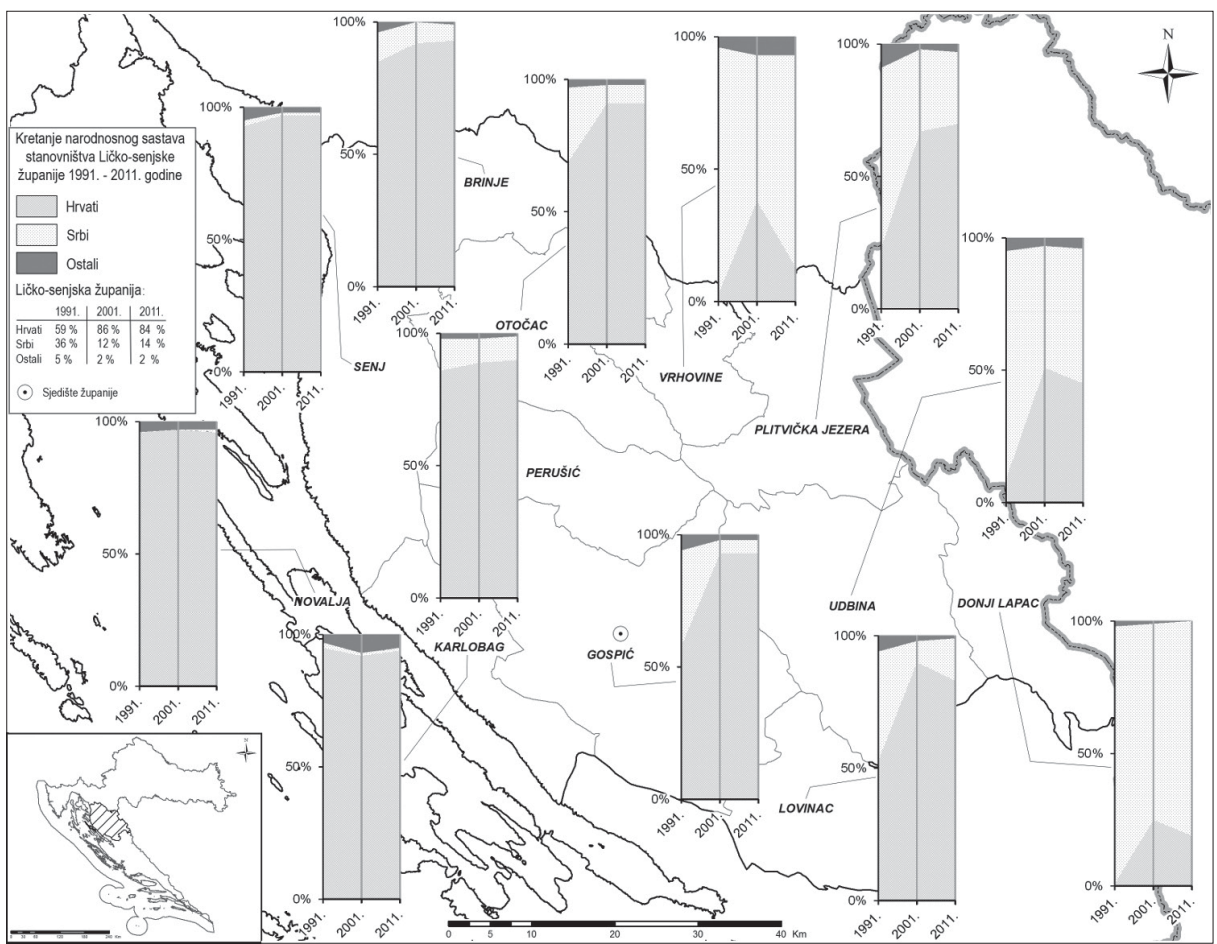

\section{ZAKLJUČAK}

Jasno je da su promjene u narodnosnom sastavu stanovništva u promatranom razdoblju ponajprije uzrokovane zbivanjima vezanim uz Domovinski rat. Ipak, navedene promjene treba razmatrati u širem kontekstu. Iz prikazanog je jasno da su promatrane dvije županije i prije Domovinskog rata imale nepovoljna demografska obilježja, a rat je sve već prisutne nepovoljne demografske (i ekonomske) procese dodatno intenzivirao. I prije Domovinskog rata promatrani prostor nije spadao u razvijene dijelove Hrvatske, a dodatni problem stvara i činjenica da su zapravo ekonomski najnerazvijeniji dijelovi proučavanih županija ujedno u Domovinskom ratu pretrpjeli i velika razaranja. Osim toga, brojne su osobe tijekom Domovinskog rata 
prisilno iselile iz ovih područja, a dio njih se još uvijek nije vratio. Povratak prognanih i izbjeglih osoba, a još više njihovih potomaka, koji su mlađe životne dobi mogao bi pridonijeli demografskoj revitalizaciji ovih županija, ili barem demografskoj stabilizaciji.

Iako Republika Hrvatska jamči svakoj prognanoj ili izbjegloj osobi mogućnost povratka, nažalost, određene u teoriji predviđene mjere nisu se realizirale u stvarnosti. Danas, dvadeset godina nakon završetka Domovinskog rata, svjedoci smo da se pojedine obitelji još nisu vratile svojim domovima, a mnoge, po svemu sudeći, nikada i neće. Prostori pogođeni Domovinskim ratom danas spadaju u slabije razvijene dijelove Hrvatske $u$ kojima nije izgledna ekonomska revitalizacija u doglednoj budućnosti. Ulaganja u razvoj ekonomije svakako bi pridonijela poboljšanju demografske slike promatranog prostora. Iluzorno je očekivati da će se bilo tko doseliti u demografski regresivan i ekonomski pasivan prostor u kojem nema zajamčenu ni osnovnu mogućnost zapošljavanja. Tu na vidjelo izlaze neizravne posljedice ratnih zbivanja, za čije će poboljšanje trebati uložiti mnogo novca tijekom duljeg razdoblja.

Ukupna se demografska situacija pogoršavala tijekom cijeloga promatranog razdoblja. U najvećem je dijelu obiju županija prisutna depopulacija. To se odnosi na ukupnu i prirodnu depopulaciju. Proces demografskog starenja vrlo je uznapredovao i uzimajući tu činjenicu u obzir, jasno je da regeneracija stanovništva temeljena na vlastitim resursima nije moguća. U uvjetima takve ostarjelosti stanovništva eventualna je regeneracija moguća jedino doseljavanjem mladog stanovništva u reproduktivnoj dobi, što bi za posljedicu moglo imati svojevrsnu supstituciju stanovništva, koja bi trebala biti planska i selektivna.

Počnu li se provoditi sveobuhvatne mjere za poticanje demografske obnove, jasno je da će se njihovi efekti vidjeti tek za dvadeset-trideset godina. Nastave li se pak ovakvi demografski tokovi, izgledno je daljnje pogoršanje već ionako krajnje lošega demografskog stanja proučavanih županija.

\section{LITERATURA}

Akrap, A. (1999). Vitalna statistika i različitost depopulacijskih procesa u Hrvatskoj i županijama, Društvena istraživanja, 10 (5-6): 793-815.

Akrap, A. i Gelo, J. (1999). Broj prisutnog stanovništva Republike Hrvatske i županija po dobi i spolu od popisa stanovništva 1991. do 1998. godine, Društvena istraživanja, 10 (5-6): 679-723. 
Akrap, A. i Gelo, J. (2009). Depopulacija Ličko-senjske županije tijekom 20. stoljeća s posebnim osvrtom na ekonomsko-socijalnu strukturu 1971. - 2001., u: Ž. Holjevac (ur.). Identitet Like - korijeni i razvitak, knj. II. Zagreb - Gospić: Institut društvenih znanosti »Ivo Pilar« - Područni centar Gospić, 13-39.

Gelo, J. (1999). Ratni učinci na promjene demografskih struktura u Hrvatskoj, Društvena istraživanja, 8 (5-6): 735-749.

Kaser, K. (1997). Slobodan seljak i vojnik: povojačenje agrarnog društva u Hrvatsko-slavonskoj Vojnoj krajini (1535. - 1881.). Zagreb: Naprijed.

Lajić, I. (2002). Hrvatske migracije početkom 21. stoljeća, Migracijske i etničke teme, 18 (2-3): 405-435.

Mesić, M. i Bagić, D. (2007). Održivost manjinskog povratka u Hrvatskoj. Zagreb: UNHCR.

Mesić, M. i Bagić, D. (2011). Manjinski povratak u Hrvatsku - studija otvorenog procesa. Zagreb: UNHCR.

Nejašmić, I. (1991). Depopulacija u Hrvatskoj - korijeni, stanje, izgledi. Zagreb: Nakladni zavod Globus - Institut za migracije i narodnosti.

Nejašmić, I. (2005). Demogeografija - stanovništvo u prostornim odnosima i procesima. Zagreb: Školska knjiga.

Nejašmić, I. (2008). Stanovništvo Hrvatske - demogeografske studije i analize. Zagreb: Hrvatsko geografsko društvo.

Nejašmić, I. (2014). Iseljavanje iz Hrvatske od 1900. do 2001.: demografske posljedice stoljetnog procesa, Migracijske i etničke teme, 30 (3): 405-435, doi: 10.11567/met.30.3.6.

Pejnović, D. (1991). Opće kretanje stanovništva kao odraz i pokazatelj socijalnogeografske diferencijacije Like, Radovi: glasilo Geografskog odjela PMF-a Sveučilišta u Zagrebu, 26: 65-76.

Pejnović, D. (1996). Geografski aspekti revitalizacije depopulacijskih i ratom pogođenih područja Hrvatske na primjeru Like, u: Z. Pepeonik (ur.). Zbornik radova 1. hrvatskoga geografskog kongresa. Zagreb: Hrvatsko geografsko društvo, 255-274.

Pejnović, D. (2004). Depopulacija županija i disparitet u regionalnom razvoju Hrvatske, Društvena istraživanja, 13 (4-5): 701-726.

Pokos, N. (1999). Procjena broja iseljenih stanovnika Republike Hrvatske od popisa stanovništva 1991. do 30. lipnja 1998. godine, Društvena istraživanja, 10 (5-6): 725-734.

Pokos, N. (2003). Metodološke promjene u popisima stanovništva, Hrvatska revija, 3 (1): 29-35.

Pokos, N. (2009). Demografske promjene na bivšim okupiranim područjima Republike Hrvatske između 1991. i 2001. godine, u: D. Živić i I. Žebec (ur.). Demografski kontekst $i$ sociokulturne posljedice Hrvatskoga domovinskog rata. Zagreb - Vukovar: Institut društvenih znanosti »Ivo Pilar« - Područni centar Vukovar, 11-27.

Radelić, Z., Marijan, D., Barić, N., Bing, A. i Živić, D. (2006). Stvaranje hrvatske države i Domovinski rat. Zagreb: Školska knjiga - Hrvatski institut za povijest.

Turk, I. (2007). Promjena broja stanovnika Karlovačke županije od 1857. do 2001. godine, Društvena istraživanja, 17 (3): 437-461.

Turk, I. (2009). Promjene u narodnosnom sastavu stanovništva Karlovačke županije (1991. - 2001.), u: D. Živić i I. Žebec (ur.). Demografski kontekst i sociokulturne posljedice Hrvatskoga domovinskog rata. Zagreb - Vukovar: Institut društvenih znanosti »Ivo Pilar« - Područni centar Vukovar, 79-94. 
Živić, D. (1999). Promjene u dinamici i razmještaju prognaničko-izbjegličkog kontingenta u Republici Hrvatskoj od sredine 1991. do sredine 1998. godine, Društvena istraživanja, 10 (5-6): 767-791.

Živić, D. (2001). Izravni demografski gubitci (ratne žrtve) Hrvatske (1990. - 1998.) uzrokovani velikosrpskom agresijom i neke njihove posljedice, Društvena istraživanja, 53 (3): 451-484.

Živić, D. (2005). Izravni i migracijski demografski gubici tijekom srbijanske oružane agresije na Hrvatsku, u: D. Živić, N. Pokos i A. Mišetić (ur.). Stanovništvo Hrvatskedosadašnji razvoj i perspektive. Zagreb: Institut društvenih znanosti »Ivo Pilar«, 71-94.

Živić, D. (2009). Demografski gubici Ličko-senjske županije u Domovinskom ratu, u: Ž. Holjevac (ur.). Identitet Like - korijeni i razvitak, knj. II. Zagreb - Gospić: Institut društvenih znanosti »Ivo Pilar« - Područni centar Gospić, 43-66.

Živić, D. (2014). Prisilne (ratne) migracije kao čimbenik demografskih promjena u Hrvatskoj (1991. - 2011.), u: A. Akrap, I. Čipin i M. Strmota (ur.). Znanstveni skup Demografija u Hrvatskoj. Zagreb: Ekonomski fakultet, 297-319.

\section{IZVORI}

Izvješće o povratku prognanika i izbjeglica u Republici Hrvatskoj 2000. - 2003., Ministarstvo za javne radove, obnovu i graditeljstvo, Zagreb, 2003.

Popis stanovništva, domaćinstava, stanova i poljoprivrednih gospodarstava 31. ožujak 1991. Narodnosni i vjerski sastav stanovništva Hrvatske 1880. - 1991. po naseljima, Državni zavod za statistiku, Zagreb, 1998.

Popis stanovništva, domaćinstava, stanova i poljoprivrednih gospodarstava 31. ožujak 1991., Stanovništvo po spolu i starosti po naseljima, dokumentacija 882, Zagreb, 1994.

Popis stanovništva, kućanstava i stanova 2001., Državni zavod za statistiku, Zagreb, www. dzs.hr.

Popis stanovništva, kućanstava i stanova 2011., Državni zavod za statistiku, Zagreb, www. dzs.hr.

Vitalna statistika RH, tablogrami, 1991. - 2012., Državni zavod za statistiku, Zagreb. 


\title{
Changes in the Ethnic Structure of the Population of Karlovac and Lika-Senj Counties in the period from 1991 to 2011
}

\author{
Ivo Turk, Nikola Šimunić, Marta Jovanić
}

SUMMARY

In this article the authors deal with the changes in the ethnic structure of Karlovac and Lika-Senj counties in the period from 1991 to 2011 and analyse the factors influencing these changes. Special attention is given to the two most represented ethnic groups in Croatia - the Croats and the Serbs. Analysing the census data the authors emphasize that the most significant changes have been registered in the first analysed inter-census period from 1991 to 2001 what is ascribed to emigration, the Croatian War of Independence, population ageing and changes in the population census methodology. According to the population census from 1991 both counties recorded the majority of residents of Croatian ethnicity, while the population of Serbian ethnic group represented the most numerous national minority counting significant proportion of $25.4 \%$ in Karlovac and $36.4 \%$ in Lika-Senj County. The 2001 population census recorded national homogenization in the ethnic structure of both counties determined by the domination of Croats (counting around $85 \%$ in both counties). The data gathered by the most recent 2011 population census have not brought any significant changes in relation to the previous ones in Karlovac County, while in some parts of Lika-Senj County they registered a significant change associated with the return of the Croatian citizens of Serbian ethnicity. The studied issue was considered in the context of highly unfavourable general demographic situation characterised by significantly pronounced processes of population ageing and depopulation as well as by adverse economic conditions in the two analysed counties.

KEY WORDS: ethnic structure, migration, depopulation, Croatian War of Independence, Karlovac County, Lika-Senj County 